\title{
PENGARUH EKONOMI MAKRO TERHADAP RISIKO SEKTORAL DI INDONESIA
}

\author{
Priyo Rokhadi Widodo \\ Tarsidin ${ }^{1}$
}

\begin{abstract}
A b s t r a ct
The disintermediation of Indonesian banking is probably due to the high level of the real sector risk. This paper analyzes the profile and the dynamics of this sectoral risk established from the median of individual firm's default risks. We measure the firm's default risk with the KMV's Expected Default Frequency (EDF). The data shows a high correlation coefficient among the sectoral risk, and through the generalized impulse response, the interrelation of the sectoral risk is revealed.

The macroeconomic variables also affect the sectoral risk. The positive shock of the BI rate, the nominal exchange rate or the inflation, causes an increase of the sectoral risk. On the other hand, a positive shock of the economic growth causes a decrease on the sectoral risk.
\end{abstract}

Keywords: Sectoral risk, default risk, probability to default

JEL Classification: G30, G33

1 Priyo Rokhadi Widodo is a Researcher and Tarsidin is a Visiting Researcher on PPSK-Bank Indonesia. priyo@bi.go.id and tarsidin@yahoo.co.id. 


\section{PENDAHULUAN}

Salah satu topik pembahasan yang menjadi fokus perhatian kita sekarang ini adalah permasalahan tidak bergeraknya sektor riil. Pada saat kondisi ekonomi makro kita semakin stabil terkendali dan sektor perbankan menunjukkan gejala over-liquid, perbankan masih enggan menyalurkan kredit sehingga sektor ini tidak mampu men-stimulus sektor riil.

Sementara itu, pergerakan dana perbankan lebih banyak di sektor keuangan yang memberikan sinyal masih adanya disintermediasi perbankan. Disintermediasi perbankan tersebut ditandai oleh tingkat Loan to Deposit Ratio (LDR) perbankan yang masih relatif rendah (sekitar 65 persen) dan masih tingginya dana sektor perbankan yang ditempatkan dalam bentuk SBI.

Salah satu hal yang diduga sebagai penyebab kondisi tersebut di atas adalah masih tingginya risiko usaha di Indonesia. Untuk membuktikan dugaan tersebut, perlu kiranya dianalisis risiko usaha di Indonesia secara lebih mendalam, antara lain dengan melakukan analisis pada level sektoral. Melalui analisis ini diharapkan dapat memberikan masukan bagi sektor perbankan mengenai tingkat risiko pada berbagai sektor usaha, yang dapat dijadikan dasar dalam penyaluran kreditnya.

Sejalan dengan hal tersebut, akan dilihat pula pengaruh variabel-variabel ekonomi makro terhadap sektor-sektor usaha di Indonesia. Variabel-variabel ekonomi makro tersebut antara lain tingkat suku bunga, inflasi, pertumbuhan ekonomi, dan nilai tukar. Variabel-variabel ekonomi makro tersebut diperkirakan akan memberikan dampak yang beragam pada sektor-sektor usaha di Indonesia. Dampak tersebut antara lain berupa penurunan/kenaikan output, produktivitas, pengangguran, dan bahkan kemungkinan bangkrutnya (default) perusahaan.

Perkiraan tentang besarnya frekuensi default perusahaan dapat menunjukkan besarnya risiko sektor usaha yang bersangkutan. Pada penelitian ini yang dimaksud dengan risiko sektoral adalah risiko per jenis usahanya, yang dapat diagregasi dari tingkat risiko sekumpulan perusahaan yang termasuk dalam masing-masing jenis usaha. Dalam hal ini digunakan pengklasifikasian jenis usaha sesuai dengan klasifikasi dari Bursa Efek Jakarta (BEJ). Mengingat keterbatasan sample, dalam hal ini perlu ditekankan bahwa tingkat risiko sektoral pada penelitian ini tidak sepenuhnya mencerminkan tingkat risiko sektor-sektor usaha tersebut pada level nasional.

Mengingat adanya keterkaitan yang erat antara satu sektor usaha dengan sektor-sektor usaha lainnya, maka besarnya frekuensi default tersebut juga akan sangat tergantung pada keeratan korelasi sektoralnya. Kemudian dapat dilihat pengaruh variabel-variabel ekonomi makro terhadap frekuensi default pada level sektoral (per jenis usaha).

Berdasarkan beberapa studi yang telah dilakukan terlihat adanya hubungan tersebut. Alves (2005) menunjukkan bahwa risiko sektoral dapat diukur dari agregasi Expected Default 
Frequency (EDF) pada level perusahaan. Dengan menggunakan Cointegrated VAR ditunjukkan adanya pengaruh korelasi sektoral dan variabel-variabel ekonomi makro terhadap tingkat risiko sektoral, di mana hasilnya menunjukkan adanya perbedaan pengaruh terhadap tingkat risiko di masing-masing sektor usaha.

Penelitian ini mengangkat tiga permasalahan, yakni:

1. Bagaimana profil risiko sektoral dari sektor-sektor usaha di Indonesia? Bagaimana pula pengaruh korelasi sektoral terhadap tingkat risiko sektoralnya?

2. Bagaimana pengaruh variabel-variabel ekonomi makro terhadap tingkat risiko sektoral?

3. Faktor-faktor apa sajakah yang berpengaruh terhadap tingkat risiko sektoral tersebut?

Manfaat yang bisa diperoleh dari penelitian ini antara lain:

1. Bagi pelaku usaha, studi/penelitian ini akan sangat bermanfaat sebagai bahan pertimbangan sebelum melakukan investasi di suatu sektor usaha.

2. Bagi perbankan, studi/penelitian ini dapat dijadikan masukan dalam mengukur besarnya default risk atas kreditnya.

3. Bagi Pemerintah dan Bank Sentral selaku pengambil kebijakan, studi/penelitian ini akan sangat bermanfaat sebagai bahan masukan bagi penyusunan regulasi, dalam upaya menekan risiko usaha di Indonesia.

\section{TEORI}

\section{II.1. Tinjauan Literatur}

\section{II.1.1. Default Risk}

Risiko dapat didefinisikan sebagai potensi terjadinya suatu peristiwa (events) yang dapat memberikan pengaruh negatif, dapat menimpa siapa saja, apa saja, kapan saja dan di mana saja. Beberapa jenis risiko yang menjadi perhatian Bank Indonesia antara lain: risiko kredit, risiko pasar, risiko likuiditas, risiko operasional, risiko hukum, risiko reputasi, risiko strategik, dan risiko kepatuhan, sebagaimana juga disebutkan Ali (2004). Sementara itu beberapa literatur membedakan jenis risiko dalam konteks portofolio assets, berupa: risiko sistematik (yang tidak dapat dieliminasi dengan diversifikasi) dan risiko non-sistematik (yang dapat dieliminasi dengan diversifikasi).

Crosbie dan Bohn (2003) menyatakan bahwa untuk mengetahui probabilitas default dan kerugian yang ditimbulkan akibat default, manajemen portofolio default risk memerlukan pengukuran korelasi default. Korelasi menghitung derajat keterkaitan default risk dari berbagai peminjam dan counterparties dalam portfolio. Elemen-elemen credit risk bisa dikelompokkan sebagai berikut: 
- Standalone Risk, meliputi:

- Default probability - kemungkinan bahwa counterparty atau peminjam akan gagal memenuhi kewajiban.

- Loss given default - besarnya kerugian yang timbul ketika peminjam atau counterparty default.

- Migration risk - kemungkinan dan pengaruh atas perubahan dalam probabilitas default.

- Portfolio Risk, meliputi:

- Default correlations - derajat untuk mengukur keterkaitan default risk peminjam dan counterparties yang ada dalam portofolio.

- Exposure - ukuran atau proporsi seberapa besar masing-masing counterparty dan peminjam terpapar default risk.

Pesaran, et. al. (2005) menyebutkan bahwa risiko kredit merupakan sumber risiko yang terbesar bagi bank. Risiko kredit terjadi akibat dari gagalnya penerima kredit (debitur) dalam memenuhi perjanjian kredit untuk melunasi pembayaran angsuran pokok dan pembayaran bunga kredit pada bank. Model risiko kredit yang standar dipelopori oleh Vasicek (1987), dan dikembangkan dalam Vasicek (1991, 2002), dan Gordy (2003), dengan mengadaptasi pendekatan option-based dari Merton (1974) dan mengakomodasi efek business cycle melalui satu atau lebih unobserved systematic risk factors. Diasumsikan bahwa proses mendapatkan nilai assets dan default threshold adalah homogen di antara perusahaan-perusahaan. Parameter dari distribusi kerugian kemudian diidentifikasi dengan menetapkan korelasi pengembalian assets antar perusahaan dan rata-rata tingkat default dari kredit portfolionya.

Crosbie dan Bohn (2003) mendefinisikan default risk sebagai ketidakpastian atas kemampuan perusahaan dalam memenuhi hutang dan kewajibannya. Studinya menghasilkan suatu metode untuk mengukur kemungkinan perusahaan default, yang besarannya disebut Expected Default Frequency (EDF). Metode ini dilakukan dengan mengestimasi nilai pasar dan pergerakan nilai assets perusahaan, kemudian menghitung standar deviasi probabilitas perusahaan tersebut default.

Sementara itu Kurbat dan Korablev (2002) mengajukan metode untuk menguji level EDF, yang dalam hal ini ditekankan pentingnya memperhatikan skewed distribution dari rata-rata default rate. Hal ini penting mengingat ukuran sample yang relatif kecil dan adanya defaults yang saling berhubungan. Jika skewness diabaikan dan hanya fokus pada rata-rata defaults rate, maka nilai EDF akan terlihat over-predict.

Di sisi lain Cipollini dan Missaglia (2006) melakukan studi empiris atas default rate sektoral dalam memodelkan portfolio credit risk. Metode yang dipakainya adalah dynamic factor analysis, yang digunakan untuk mengukur dampak dari shock terhadap distribusi kerugian atas portofolio 
kredit bank. Sebagaimana studi lainnya, pengaruh business cycle juga diakomodasi dalam modelnya.

\section{II.1.2. Faktor-faktor yang Mempengaruhi Risiko}

Besarnya default risk dapat diukur dengan probabilitas default-nya. Crosby dan Bohn (2003) menyebutkan bahwa terdapat tiga elemen utama dalam menentukan besarnya probabilitas default suatu perusahaan, yakni:

- Nilai assets: nilai pasar dari assets perusahaan, mengukur prospek perusahaan dan memperhitungkan pula informasi yang relevan terkait dengan bisnis perusahaan dan kondisi perekonomian.

- Risiko assets: ketidakpastian atau risiko dari nilai assets, mengukur risiko bisnis perusahaan dan industri.

- Leverage: merupakan ukuran tingkat hutang perusahaan terhadap besarnya nilai assets perusahaan.

Alves (2005), menggunakan market-based information untuk mengukur besarnya sectoral fragility yang dianalisis dengan menggunakan metode Cointegrated VAR, didapatkan bahwa ada tiga faktor yang menentukan besarnya risiko pada suatu sektor. Faktor pertama, yakni adanya cross-dynamics dalam transmisi baik antar industri maupun dalam suatu rentang periode. Faktor kedua, adalah adanya indikasi bahwa long-run equilibrium turut berperan terhadap besarnya risiko sektoral. Di samping itu faktor-faktor ekonomi makro dan sistemik berpengaruh terhadap steady state level dari risiko tersebut. Faktor ketiga meliputi faktor-faktor yang tidak tergantung pada kinerja ekonomi, dan oleh karena itu unobservable.

Pengaruh ekonomi makro terhadap besarnya risiko sektoral juga dianalisis oleh Pesaran, et. al. (2005). Analisis tersebut dilakukan dengan menggunakan dynamic global macroeconometric model, didapat bahwa dampak variabel ekonomi makro dapat dipisahkan dari shock yang bersifat idiosyncratic. Kemungkinan default suatu perusahaan juga dipengaruhi oleh keeratannya dengan business cycle, baik firm-specific, domestik, maupun internasional.

Sejalan dengan Pesaran (2005), Sorge dan Virolainen (2006) menemukan bahwa resesi secara signifikan membuat risiko default industri lebih besar dibandingkan dengan kondisi rata-rata terjadinya default. Dengan menggunakan data Finlandia pada awal tahun 1990-an, ditemukan adanya hubungan yang signifikan antara tingkat default pada beberapa industri dengan indikator ekonomi utama seperti GDP, suku bunga dan hutang perusahaan. Diketahui pula bahwa adanya dependensi antara terjadinya default dengan lag dari indikator-indikator aktivitas ekonomi. 


\section{II.2. Kerangka Konseptual}

\section{II.2.1. Default Risk dan Faktor-faktor yang Mempengaruhinya}

Sebagaimana diuraikan di muka, tingginya default risk suatu perusahaan dipengaruhi oleh beberapa faktor. Default suatu perusahaan secara langsung terkait dengan kinjpja perusahaan yang bersangkutan. Selain itu juga dipengaruhi oleh berbagai faktor lainnya, seperti keterkaitan antar perusahaan (baik dalam satu sektor usaha maupun antar sektor usaha) dan kondisi ekonomi makro. Dengan kata lain faktor-faktor yang mempengaruhi kemungkinan default perusahaan, dapat dikelompokkan menjadi faktor-faktor pada level perusahaan, industri, dan nasional.

Dinamika dari ketiga level faktor-faktor yang mempengaruhi kemungkinan defaultsuatu perusahaan menunjukkan bahwa default suatu perusahaan dapat diikuti oleh default perusahaan-perusahaan lainnya, baik dalam satu sektor usaha maupun antar sektor usaha. Demikian pula meningkatnya risiko suatu sektor usaha, yang ditunjukkan dengan besarnya kemungkinan default perusahaan-perusahaan pada sektor usaha tersebut, juga dapat menyebabkan meningkatnya risiko pada sektor-sektor usaha lainnya, bahkan risiko pada kondisi ekonomi suatu negara. Maka dari itu, dapat disimpulkan bahwa meningkatnya risiko suatu perusahaan, sektor usaha, dan kondisi ekonomi makro dapat disebabkan oleh meningkatnya risiko pada perusahaan atau sektor lainnya, juga oleh kondisi ekonomi makronya. Hal ini menunjukkan adanya hubungan impulse-response risiko yang terjadi secara simultan.

Mengingat adanya korelasi antar perusahaan, sektor usaha, dan kondisi ekonomi makro yang mempengaruhi besarnya risiko, baik pada level perusahaan, sektor usaha, dan nasional, langkah pertama dalam menganalisis risiko sektoral adalah mengukur besarnya korelasi tersebut, setelah tentunya mendapatkan besaran risiko pada level perusahaan dan mengagreasinya menjadi risiko pada level sektoral. Langkah selanjutnya adalah melihat respon risiko sektoral tersebut dalam menghadapi variabel eksternal, dalam hal ini shock ekonomi makro.

\section{II.2.2. Risiko Sektoral}

Besarnya risiko sektoral diperoleh dengan mengagregasi risiko atau kemungkinan default perusahaan-perusahaan yang masuk dalam kelompok sektor usaha tersebut. Penghitungan besarnya default risk suatu perusahaan dalam penelitian ini menggunakan pendekatan dari Crosbie dan Bohn (2005). Default risk perusahaan meningkat ketika nilai pasar assets-nya mendekati nilai buku hutangnya dan perusahaan akan default ketika market net worth-nya bernilai 0 . Besaran kemungkinan default suatu perusahaan, yang ditunjukkan dengan ukuran Expected Default Frequency (EDF), menunjukkan besarnya risiko suatu perusahaan. 
Mengingat adanya keterkaitan antar sektor usaha, diperkirakan kinerja dan risiko suatu sektor usaha akan berpengaruh terhadap kinerja dan risiko sektor-sektor usaha lainnya. Korelasi risiko antar sektor usaha tersebut diperkirkan mempunyai pola atau hubungan fungsional tertentu, mengingat struktur input-output antar sektor usaha dan koefisien teknologinya relatif tetap. Memahami korelasi risiko sektoral merupakan langkah awal sebelum melakukan analisis dalam konteks yang lebih kompleks dan dinamis. Hal tersebut dilakukan dengan cara memasukkan beberapa variabel lainnya, mengendogenkan risiko sektoral, dan memasukkan unsur waktu dalam analisisnya.

\section{II.2.3. Dinamika Risiko Sektoral}

Sebagaimana disebutkan di muka risiko sektoral dipengaruhi oleh keterkaitan antar sektor usaha dan variabel-variabel ekonomi makro, seperti tingkat suku bunga SBI, nilai tukar, inflasi, dan pertumbuhan ekonomi. Risiko sektoral dalam hal ini merupakan variabel endogen, yang nilainya ditentukan dalam sistem. Sementara itu tingkat risiko pada level nasional juga dipengaruhi oleh risiko sektoral tersebut. Dengan demikian risiko sektoral juga akan mempengaruhi kondisi ekonomi makro.

Model dinamika risiko sektoral tersebut di atas dapat dituliskan dalam bentuk sistem VAR sebagai berikut:

$$
\Gamma \boldsymbol{y}_{t}=B(L) \boldsymbol{y}_{t}+e_{t}
$$

di mana:

$\boldsymbol{y}_{t} \quad$ : vektor variabel-variabel endogen, terdiri dari 9 variabel risiko sektoral dan 4 variabel ekonomi makro

$B(L)$ : koefisien lag polynomial

Dari model tersebut terlihat bahwa risiko sektor usaha i dipengaruhi oleh risiko sektorsektor usaha lainnya (termasuk lag-nya), di samping tentunya dipengaruhi pula oleh variabelvariabel ekonomi makro. Mengingat keterkaitan antar sektor usaha berhubungan dengan struktur input-outputnya, maka perlu dianalisis pula kemungkinan adanya hubungan fungsional dalam jangka panjang antar sektor-sektor usaha tersebut. 


\section{METODOLOGI}

\section{III.1. Metode Estimasi}

Sebagaimana disebutkan di muka, meningkatnya risiko perusahaan dan risiko suatu sektor usaha dapat disebabkan oleh meningkatnya risiko pada perusahaan atau sektor usaha lainnya, di samping tentunya juga dipengaruhi oleh kondisi ekonomi makro. Hal ini menunjukkan adanya hubungan impulse-response risiko yang terjadi secara simultan.

Berdasarkan hasil pengujian unit roots sebagaimana disebutkan di bagian berikutnya, terlihat bahwa sebagian besar variabel stasioner. Dengan demikian tidak dilakukan cointegration test untuk menguji kemungkinan adanya hubungan fungsional antar sektor usaha dalam jangka panjang. Berdasarkan kondisi variabel yang sebagian besar I(0) tersebut, metode yang dinilai tepat untuk menganalisis pengaruh shock variabel-variabel ekonomi terhadap besarnya risiko sektoral di Indonesia adalah Vector Autoregression (VAR). Dengan menggunakan generalized impulse response dari sistem VAR tersebut dapat diketahui pengaruh shock risiko sektor usaha tertentu terhadap risiko pada sektor usaha lainnya, juga pengaruh shock variabel-variabel ekonomi makro terhadap risiko pada suatu sektor usaha.

\section{III.2. Pengumpulan dan Pengolahan Data}

Penelitian ini menggunakan data sekunder, yang diperoleh dari CEIC, BEJ, Bank Indonesia, dan berbagai publikasi lainnya. Periode observasi dari tahun 1998-2006, dengan menggunakan data kuartalan. Jumlah observasi sebanyak 158 perusahaan, meliputi 9 sektor usaha. Representasi sample pada masing-masing sektor usaha adalah sebagai berikut:

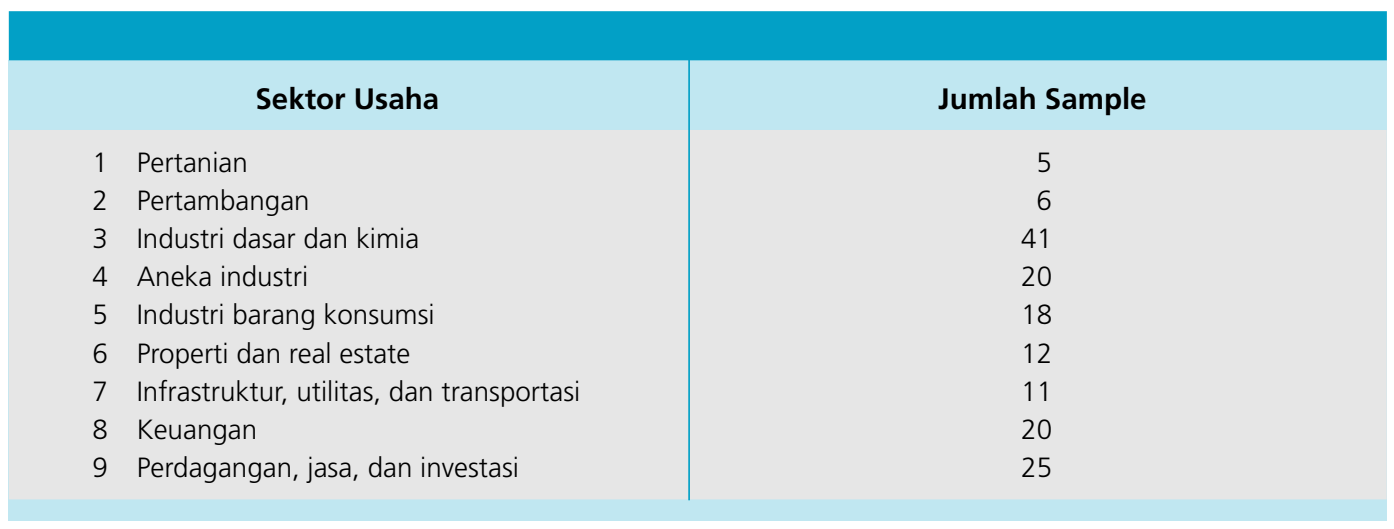

Beberapa data yang diperlukan antara lain berasal dari Laporan Keuangan perusahaan, publikasi harga saham perusahaan di BEJ, dan berbagai variabel ekonomi makro. Mengingat 
ketidaktersediaan data empiris tentang besarnya persentase default yang terjadi pada perusahaan-perusahaan di Indonesia yang dikelompokkan per sektor usaha, maka digunakan asumsi bahwa asset return perusahaan terdistribusi normal. Asumsi ini diperlukan dalam menentukan probability to default dari besaran distance to default masing-masing perusahaan.

\section{III.3. Risiko Sektoral}

Penghitungan besaran default risk (default probability) suatu perusahaan dalam penelitian ini menggunakan pendekatan dari Crosbie dan Bohn (2005), yang disebut KMV's Expected Default Frequency (EDF). Pendekatan tersebut didasarkan pada Black-Scholes-Merton framework yang diperkenalkan oleh Oldrich Vasicek dan Stephen Kealhofer, yang dikenal sebagai model vasicek-Kealhofer (VK).

Untuk menghitung kemungkinan default suatu perusahaan diperlukan data dan informasi sebagai berikut:

1) Market value of assets

Nilai pasar dari assets perusahaan menunjukkan berapa besar nilai harta perusahaan yang dapat digunakan untuk menutup kewajiban perusahaan. Nilai pasar assets tersebut dihitung dengan pendekatan Black-Scholes option-pricing model.

\section{2) Asset volatility}

Asset volatility merupakan suatu ukuran risiko assets perusahaan, yang diukur dari besarnya standar deviasi nilai assets tersebut. Besaran asset volatility tersebut dihitung dengan pendekatan Black-Scholes option-pricing model.

3) Default point

Default point ditunjukkan dengan besaran nilai buku kewajiban perusahaan yang segera jatuh tempo, yakni nilai buku current liabilities perusahaan. Datanya diperoleh dari Laporan Keuangan perusahaan. Namun untuk perusahaan yang bergerak di bidang real estate dan lembaga keuangan bank dan non-bank digunakan nilai buku total liabilities-nya, mengingat Laporan Keuangannya tidak secara eksplisit mengklasifikasikan kewajiban perusahaan menjadi current dan long-term liabilities.

\section{4) Market value of equity}

Data nilai pasar dari equity perusahaan diperoleh dengan mengalikan jumlah lembar saham (yang datanya berasal dari Laporan Keuangan perusahaan) dengan harga saham pada penutupan perdagangan di tiap kuartalnya. 
5) Equity volatility

Besaran equity volatility diperoleh dari standar deviasi share price return perusahaan selama empat kuartal terakhir. Dengan demikian diperoleh besaran equity volatility yang ter-update pada tiap kuartalnya.

6) Distibusi nilai assets

Dalam hal ini diasumsikan bahwa nilai assets pada horizon terdistribusi normal.

7) Expected rate of return atas nilai assets tersebut sepanjang horizon

Besaran expected rate of return, yang menunjukkan tingkat pertumbuhan assets, diasumsikan sebesar tingkat pertumbuhan GDP nominal pada kuartal yang bersangkutan.

8) Risk-free rate

Dalam hal ini digunakan tingkat suku bunga SBI periode 1 bulan.

9) Panjang horizonnya

Mengingat datanya adalah kuartalan, maka panjang horizonnya ditetapkan sebesar $\mathrm{t}=4$, yakni satu tahun.

Black-Scholes option-pricing model untuk menghitung market value of assets dan asset volatility tersebut dijalankan dengan menyelesaikan kedua persamaan berikut secara simultan.

$$
\begin{aligned}
& V_{E}=V_{A} N(d 1)-e^{-r T} X N(d 2) \text { dan } \\
& \sigma_{E}=\frac{V_{A}}{V_{E}} \Delta \sigma_{A}
\end{aligned}
$$

di mana:

$V_{E}:$ market value of equity

$V_{A}:$ market value of assets

$\sigma_{E}:$ equity volatility

$\sigma_{A}:$ asset volatility

$X \quad$ : nilai buku current liabilities

$r$ : risk-free rate

$T$ : time horizon

$N$ : normal cumulative distribution function 


$$
\begin{aligned}
& d 1=\frac{\ln \left(\frac{V_{A}}{X}\right)+\left(r+\frac{\sigma_{A}^{2}}{2}\right) T}{\sigma_{A} \sqrt{T}} \\
& d 2=d 1-\sigma_{A} \sqrt{T} \\
& \Delta=N(d 1)
\end{aligned}
$$

Dari data dan informasi tersebut di atas, dapat dihitung besarnya distance to default, yang mengkombinasikan informasi tentang besarnya nilai assets, business risk (yang tercermin dari asset volatiltiy-nya), dan leverage (yang ditunjukkan dengan debt to equity ratio-nya, yang kemudian tercermin dari besaran market net worth-nya). Distance to default tersebut merupakan suatu ukuran default risk, yang pada dasarnya membandingkan besarnya market net worth terhadap besaran standar deviasi dari assets-nya, yang dapat dirumuskan sebagai berikut:

$$
D D=\frac{V_{A}-X}{V_{A} \cdot \sigma_{A}}
$$

di mana:

DD : distance to default

$V_{A} \quad$ : market value of assets

$\sigma_{A}:$ asset volatility

$X \quad$ : default point

Dalam konteks Black-Scholes-Merton framework, distance to default tersebut dapat dirumuskan sebagai berikut:

$$
D D=\frac{\ln \frac{V_{A}}{X_{t}}+\left(\mu-\frac{\sigma_{A}^{2}}{2}\right) t}{\sigma_{A} \sqrt{t}}
$$

di mana:

$\mu \quad$ : expected return atas assets perusahaan

Langkah selanjutnya adalah menghitung besaran probability to default, yang dinamakan Expected Default Frequency (EDF), yang dapat dihitung langsung dari distance to default jika probability distribution dari assets diketahui. Dengan asumsi bahwa asset return dari perusahaan terdistribusi normal, maka probability to default tersebut dapat dirumuskan sebagai berikut: 


$$
P D_{t}=N\left[\frac{\ln \frac{V_{A}}{X_{t}}+\left(\mu-\frac{\sigma_{A}^{2}}{2}\right) t}{\sigma_{A} \sqrt{t}}\right]
$$

di mana:

$P D$ : probability to default (EDF)

Langkah-langkah (prosedur) tersebut di atas dapat digambarkan sebagai berikut:

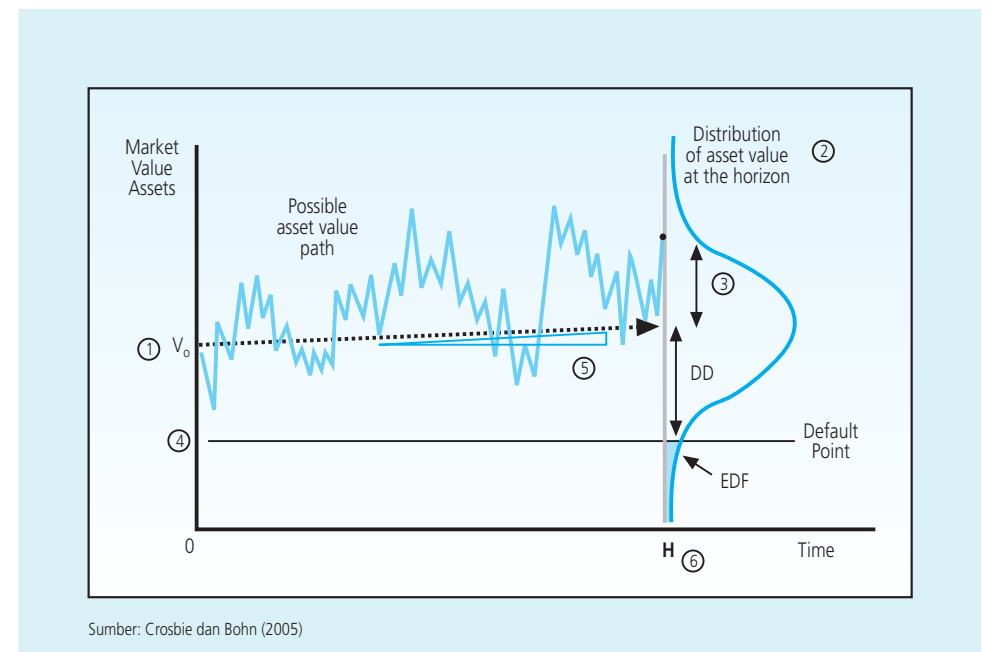

Gambar II.1 Estimasi Expected Default Frequency (EDF)

Sementara itu besarnya risiko sektoral dapat dihitung dari median EDF tiap sektor usaha, sebagaimana juga digunakan oleh Alves (2005). Jadi dari beberapa EDF perusahaan yang dijadikan sample atas suatu sektor usaha dicari median-nya, sebagai representasi dari probabilitiy to default (risiko) sektor usaha yang bersangkutan. Agregasi sektoral dengan menggunakan median dipilih mengingat beberapa pertimbangan, yakni: sample median tersebut akan konvergen ke population mean-nya jika distribusi populasi simetris serta median tersebut robust terhadap sample outlier, meskipun di sisi lain tidak dapat mengakomodasi potential risk pada salah satu sisi distribusi EDF tersebut dan tidak memberi bobot terhadap besarnya risiko perusahaan, sebagaimana disebutkan Alves (2005). Median tersebut dipilih karena adanya keterbatasan jumlah sample dan tidak dilakukannya estimasi untuk mengukur bobot tiap sample, sehingga tidak tepat untuk menggunakan sample mean sebagai ukuran risiko sektoral. 
Sebagaimana disebutkan di muka, sample yang digunakan adalah dari perusahaan-perusahaan yang listing di BEJ, yang dipilih lebih karena ketersediaan datanya dan komposisinya tidak mencerminkan kontribusi sektoralnya.

Untuk mengukur besarnya korelasi di antara risiko-risiko sektoral tersebut, digunakan ukuran coefficient of correlation. Besarnya korelasi antar sektor usaha tersebut sangat diperlukan sebagai langkah awal dalam memahami dinamika risiko sektoral, yakni adanya pengaruh risiko suatu sektor usaha terhadap risiko sektor usaha lainnya.

\section{III.4. Dinamika Risiko Sektoral}

Sebagaimana disebutkan di muka, model untuk melihat dinamika risiko sektoral adalah sebagai berikut:

$$
\Gamma \boldsymbol{y}_{t}=B(L) \boldsymbol{y}_{t}+e_{t}
$$

di mana:

$\boldsymbol{y}_{t} \quad$ : vektor variabel-variabel endogen, terdiri dari 9 variabel risiko sektoral dan 4 variabel ekonomi makro

$B(L)$ : koefisien lag polynomial

Sementara itu ordering dari variabel-variabel dalam sistem VAR tersebut adalah sebagai berikut:

$$
\left[\begin{array}{llllllllllllll}
i_{t} & y_{t} & \pi_{t} & S_{t} & r_{1, t} & r_{2, t} & r_{3, t} & r_{4, t} & r_{5, t} & r_{6, t} & r_{7, t} & r_{8, t} & r_{9, t}
\end{array}\right]
$$

di mana:

$i \quad$ : tingkat suku bunga SBI

$y \quad$ : pertumbuhan GDP riil

$\pi \quad$ : tingkat inflasi

$S \quad$ : nilai tukar nominal

$r_{i} \quad$ : risiko sektor i

Mengingat hubungan sektoral yang cukup kompleks sehingga urutan pengaruh dari suatu sektor usaha ke sektor usaha lainnya tidak dapat ditentukan dengan pasti, maka digunakan generalized impulse response, sebagaimana disarankan oleh Pesaran dan Shin (1998). Generalized impulse response tersebut tidak berdasarkan order VAR sebagaimana disebutkan di atas, melainkan dengan menjadikan variabel di mana shock timbul sebagai variabel pertama pada Cholesky ordering. 
Sementara itu untuk melihat hubungan risiko antar sektor usaha, digunakan sistem VAR yang hanya terdiri dari variabel $r_{i^{\prime}}$ yakni risiko sektor dari ke-9 sektor usaha tersebut (tanpa melibatkan variabel-variabel ekonomi makro). Hal ini dilakukan mengingat sample dari ke-9 sektor usaha tersebut relatif kecil dibandingkan dengan keseluruhan perekonomian, sehingga tidak tepat jika dimodelkan bahwa risiko sektoral mempengaruhi variabel-variabel ekonomi makro.

Dalam hal ini perlu diperhatikan bahwa periode observasi yang relatif sedikit (yakni tahun 1998 - 2006 dengan menggunakan data kuartalan) dibandingkan dengan jumlah variabel pada sistem VAR tersebut tentunya dapat mengurangi akurasi hasil estimasi.

\section{ANALISIS DAN PEMBAHASAN}

\section{IV.1. Risiko Sektoral}

Sebagaimana disebutkan di muka risiko sektoral dibentuk dari median probabilitas default perusahaan-perusahaan yang tergabung dalam suatu sektor usaha. Dengan demikian tingkat risiko sektoral yang rendah bukan berarti tidak ada perusahaan dalam kelompok sektor usaha

SEKTOR 1

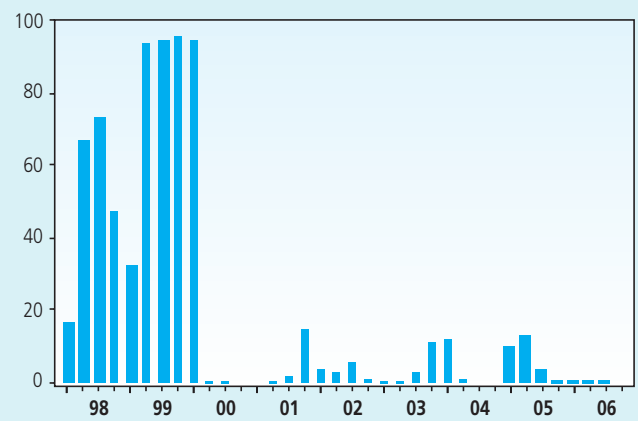

SEKTOR _ 3

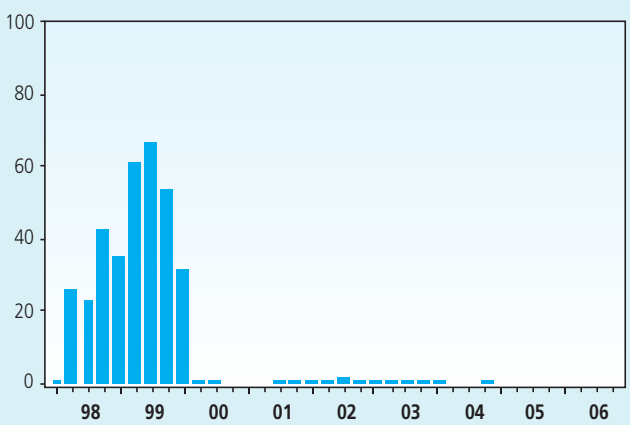

SEKTOR 2

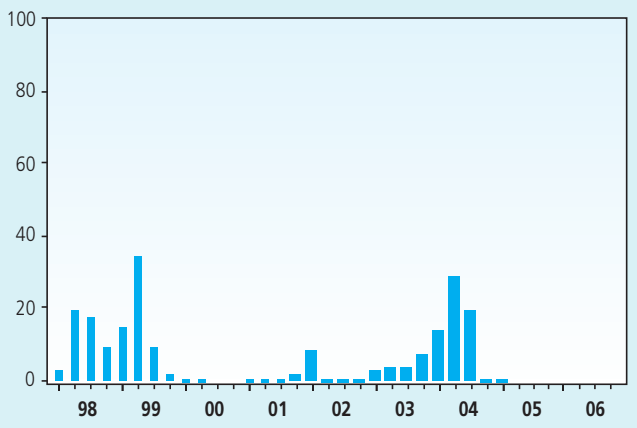

SEKTOR _ 4

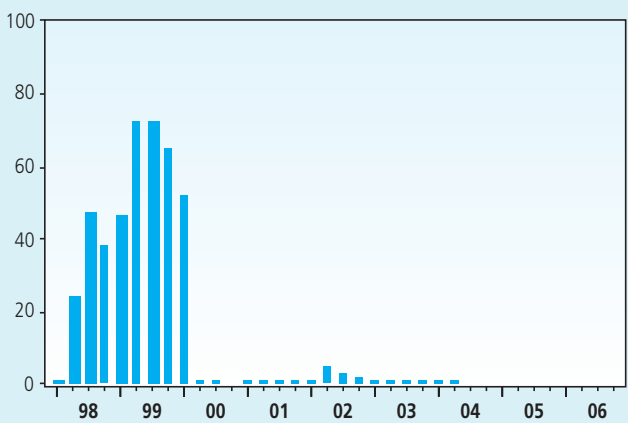

Gambar II.2 Risiko Sektoral 
SEKTOR 5

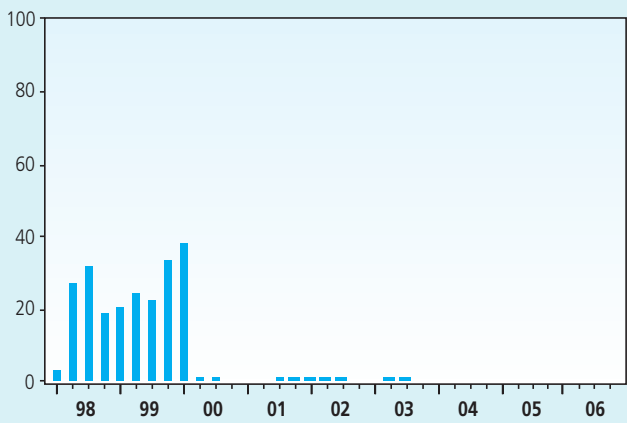

SEKTOR 7

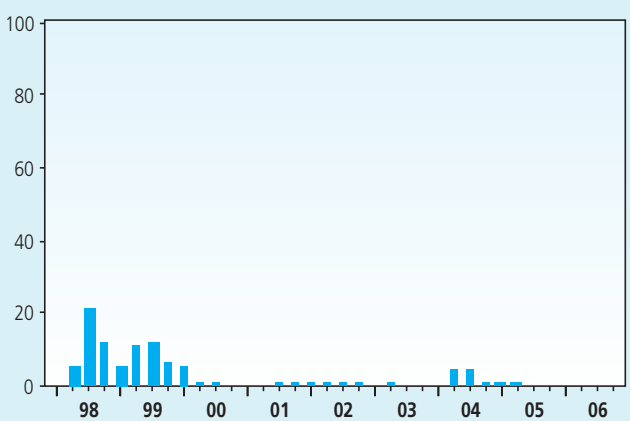

SEKTOR 9

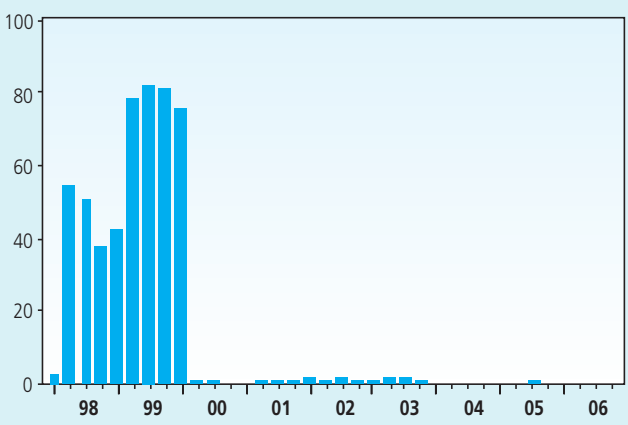

SEKTOR 6

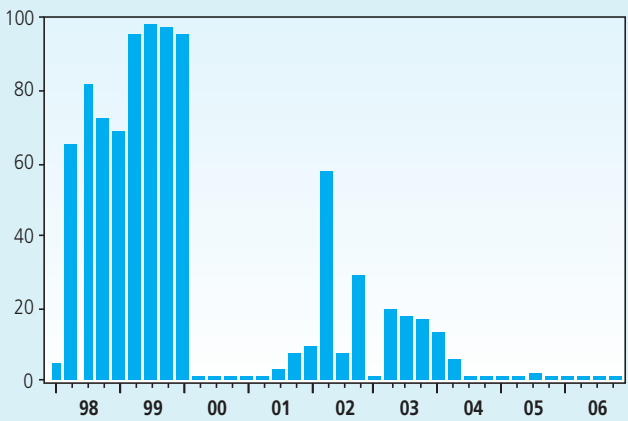

SEKTOR_ 8

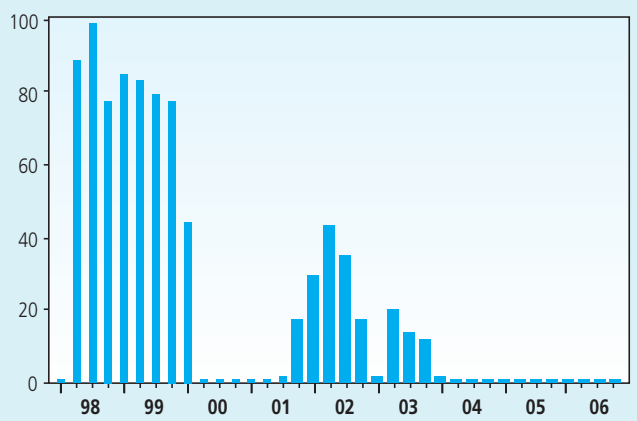

Gambar II.2 Risiko Sektoral (lanjutan)

tersebut yang probabilitas default-nya tinggi, demikian pula sebaliknya. Sebagai gambaran, berikut ini adalah perkembangan risiko sektoral tiap sektor usaha selama periode observasi.

Dari gambaran tersebut terlihat adanya pola yang mirip antar default di tiap sektor usaha. Probability to default tertinggi terjadi pada masa krisis tahun 1998 - 1999. Pada masa tersebut probability to default tertinggi dialami oleh sektor pertanian, properti dan real estate, serta 
keuangan, sedangkan yang relatif rendah dialami oleh sektor infrastruktur, utilitas, dan transportasi, serta pertambangan. Setelah periode krisis, probability to default sektor-sektor usaha mengalami penurunan, bahkan beberapa di antaranya mendekati level 0 . Namun sektor pertambangan, properti dan real estate, serta keuangan mengalami lonjakan probability to defaut yang cukup besar pada tahun 2002 - 2004. Untuk mengetahui penyebab hal tersebut, pada bagian berikutnya akan dilihat hubungan antara variabel-variabel ekonomi makro dan risiko sektoral tersebut. Tingginya EDF sektor properti dan real estate dan sektor keuangan juga terkait dengan digunakannya total liabilities sebagai default point-nya.

Sementara itu untuk melihat kuatnya hubungan antar sektor usaha, bisa dilihat dari coefficient of correlation-nya, sebagaimana ditunjukkan berikut ini.

\begin{tabular}{l|c|c|c|c|c|c|c|c|c|}
\multicolumn{7}{c}{ Coefficient of Correlation Risiko Sektoral } \\
& SEKTOR_1 & SEKTOR_2 & SEKTOR_3 & SEKTOR_4 & SEKTOR_5 & SEKTOR_6 & SEKTOR_7 & SEKTOR_8 & SEKTOR_9 \\
SEKTOR_1 & 1 & 0.4220 & 0.9206 & 0.9497 & 0.9518 & 0.9247 & 0.7686 & 0.8374 & 0.9823 \\
SEKTOR_2 & 0.4220 & 1 & 0.456 & 0.4459 & 0.3885 & 0.4253 & 0.6138 & 0.4926 & 0.4287 \\
SEKTOR_3 & 0.9206 & 0.4559 & 1 & 0.9760 & 0.8570 & 0.9102 & 0.7592 & 0.8529 & 0.9551 \\
SEKTOR_4 & 0.9497 & 0.4459 & 0.9760 & 1 & 0.9138 & 0.9425 & 0.8011 & 0.8699 & 0.9761 \\
SEKTOR_5 & 0.9518 & 0.3885 & 0.8570 & 0.9138 & 1 & 0.9188 & 0.7757 & 0.8620 & 0.9547 \\
SEKTOR_6 & 0.9247 & 0.4253 & 0.9102 & 0.9425 & 0.9188 & 1 & 0.7702 & 0.9221 & 0.9399 \\
SEKTOR_7 & 0.7686 & 0.6138 & 0.7592 & 0.8011 & 0.7757 & 0.7702 & 1 & 0.8096 & 0.7561 \\
SEKTOR_8 & 0.8374 & 0.4926 & 0.8529 & 0.8699 & 0.8620 & 0.9221 & 0.8096 & 1 & 0.8582 \\
SEKTOR_9 & 0.9823 & 0.4287 & 0.9551 & 0.9761 & 0.9547 & 0.9399 & 0.7561 & 0.8582 & 1
\end{tabular}

Dari tabel coefficient of correlation tersebut terlihat bahwa keterkaitan probability to default (EDF) antar sektor usaha sangat tinggi, rata-rata berkisar 0,70-0,90. Hal ini tentunya semakin menguatkan hipotesis adanya keterkaitan risiko antar sektor usaha sehubungan dengan struktur input-outputnya (hubungan backward dan forward-nya). Dinamika probability to default dari sektor-sektor usaha ketika terjadi shock risiko pada suatu sektor usaha lain akan dianalisis bersama-sama dengan analisis atas pengaruh shock ekonomi makro.

\section{IV.2. Pengaruh Ekonomi Makro terhadap Risiko Sektoral}

Beberapa variabel ekonomi makro yang diperkirakan berpengaruh signifikan terhadap risiko sektoral adalah: tingkat suku bunga SBI, nilai tukar, inflasi, dan pertumbuhan ekonomi. Dalam hal ini variabel tingkat suku bunga SBI menunjukkan besaran per tahun pada kuartal yang bersangkutan, sedangkan variabel tingkat inflasi dan pertumbuhan ekonomi menunjukkan besaran per kuartalnya dan variabel nilai tukar dalam bentuk natural log. 
BIRATE

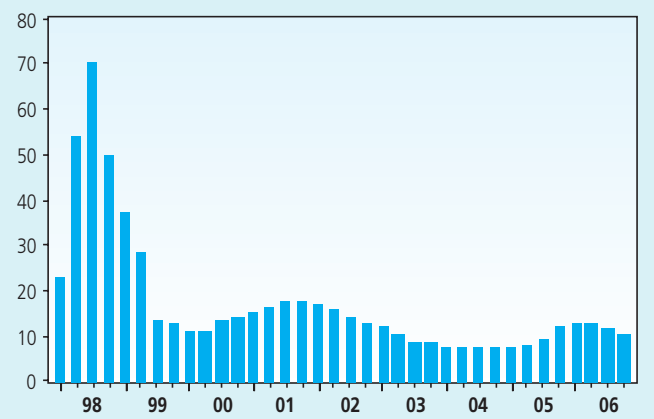

GDPGROWTH

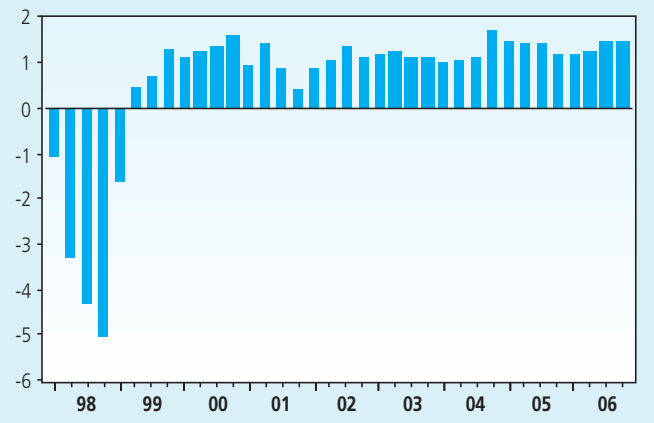

LEXRATE

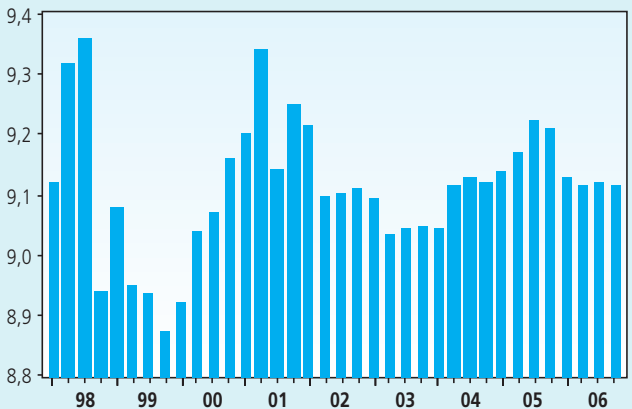

INFLASI

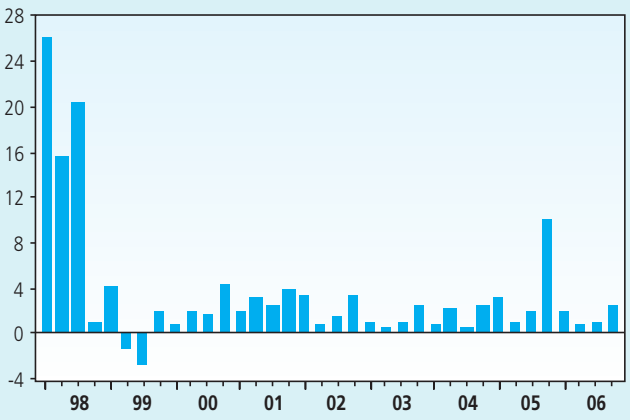

Gambar II.3 Variabel-variabel Ekonomi Makro

Pengujian unit roots untuk melihat stasioneritas data dilakukan dengan ADF test, berdasarkan sequential testing procedure dari Perron, sebagaimana disebutkan Harris (1995). Dengan menggunakan Schwarz Info Criterion dan lag maksimum 9, hasilnya adalah sebagai berikut:

\begin{tabular}{c|c|l}
\multicolumn{2}{c}{} & \multicolumn{2}{c}{ Tabel II.2 } \\
& & Pengujian Unit Roots \\
Variabel & ADF t-test & \multicolumn{1}{c}{ Keterangan } \\
Sektor_1 & $-1,803154^{*}$ & signifikan pada level 10\% dengan tanpa trend dan intercept. \\
\hline Sektor_2 & $-3,283449^{*}$ & signifikan pada level 10\% dengan full-specification. \\
\hline Sektor_3 & $-2,464257$ & tidak signifikan baik dengan full-specification maupun hanya \\
& dengan intercept atau tanpa trend dan intercept. \\
\hline Sektor_4 & $-3,803824^{* *}$ & signifikan pada level 5\% dengan full-specification. \\
\hline Sektor_5 & $-8,702927^{* * *}$ & signifikan pada level 1\% dengan full-specification. \\
\hline Sektor_6 & $-5,137045^{* * *}$ & signifikan pada level 1\% dengan full-specification. \\
\hline Sektor_7 & $-3,582107^{* *}$ & signifikan pada level 5\% dengan full-specification. \\
\hline Sektor_8 & $-7,133365^{* * *}$ & signifikan pada level 1\% dengan intercept. \\
\hline Sektor_9 & $-1,628643^{*}$ & signifikan pada level 1\% dengan tanpa trend dan intercept. \\
\hline
\end{tabular}




\begin{tabular}{c|c|c}
\multicolumn{2}{c}{} & \multicolumn{2}{c}{$\begin{array}{c}\text { Tabel II.2 } \\
\text { Pengujian Unit Roots (lanjutan) }\end{array}$} \\
\hline Variabel & ADF t-test & \multicolumn{1}{c}{ Keterangan } \\
BIRATE & $-1,597034$ & $\begin{array}{l}\text { tidak signifikan baik dengan full-specification maupun hanya } \\
\text { dengan intercept atau tanpa trend dan intercept. }\end{array}$ \\
\hline LEXRATE & $-5,586467 * * *$ & signifikan pada level 1\% dengan intercept. \\
\hline INFLASI & $-3,388556^{*}$ & signifikan pada level 10\% dengan full-specification. \\
\hline GDPGROWTH & $-1,741451^{*}$ & signifikan pada level 10\% dengan tanpa trend dan intercept. \\
\hline
\end{tabular}

Dari hasil pengujian unit roots tersebut, terlihat bahwa sebagian besar variabel I(0) dan hanya beberapa variabel yang I(1). Pada first difference-nya, variabel-variabel yang I(1) tersebut stasioner.

Pemilihan lag yang optimal yang dimulai dari lag terpanjang, menghasilkan optimal lag sebanyak 1. Estimasi pada model tersebut hanya dapat dilakukan dengan lag maksimum sebanyak 2, mengingat keterbatasan jumlah observasi. Pada lag 2, sistem VAR memenuhi kondisi stabilitas, namun tidak dapat ditentukan lag optimalnya. Oleh karena itu dipilih optimal lag 1.

Generalized Impulse response dari variabel risiko sektoral dan variabel-variabel ekonomi makro tersebut sebagai berikut:
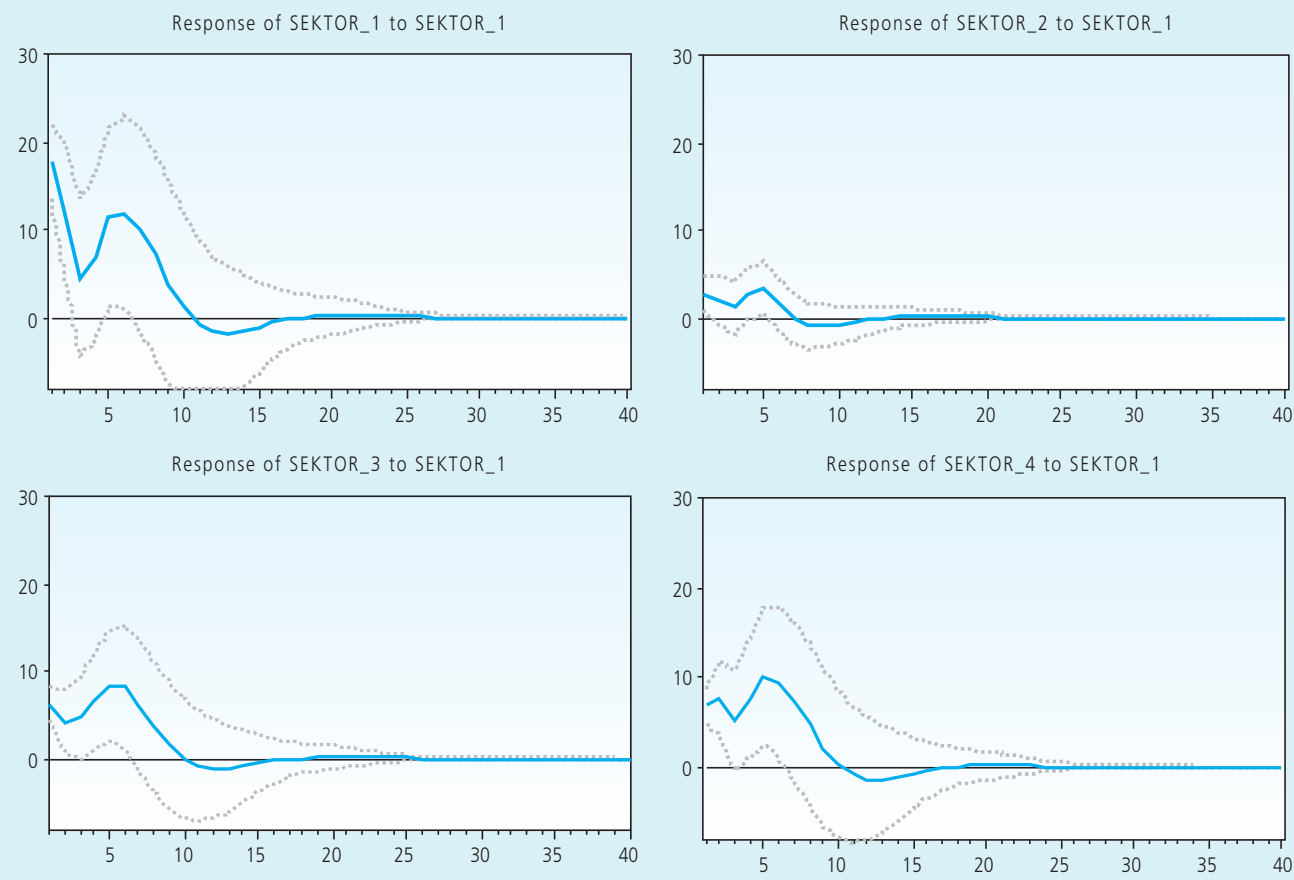

Gambar II.4 Generalized Impulse Response Shock Risiko Sektor Pertanian (Sektor 1) 
Response of SEKTOR_5 to SEKTOR_1

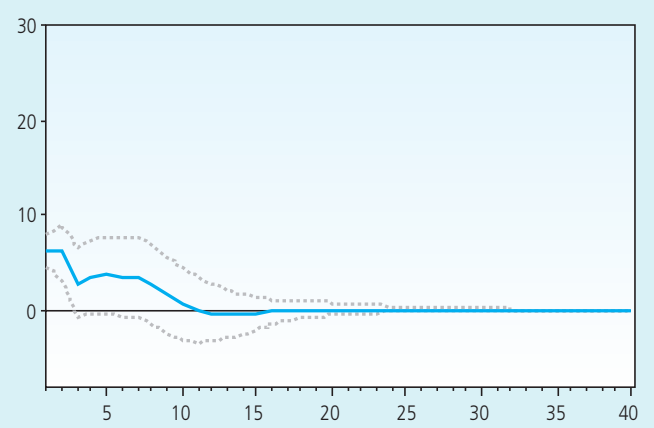

Response of SEKTOR_7 to SEKTOR_1

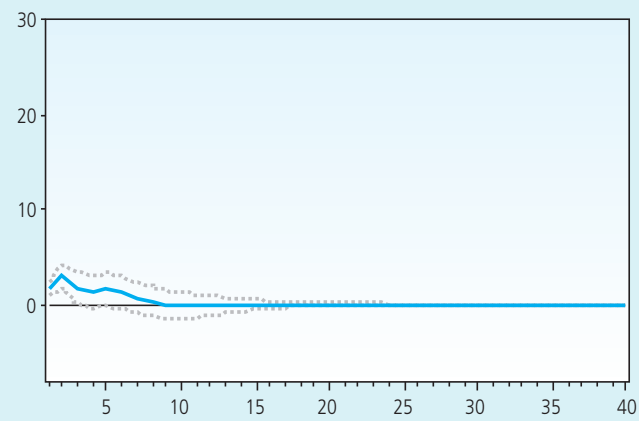

Response of SEKTOR_9 to SEKTOR_1

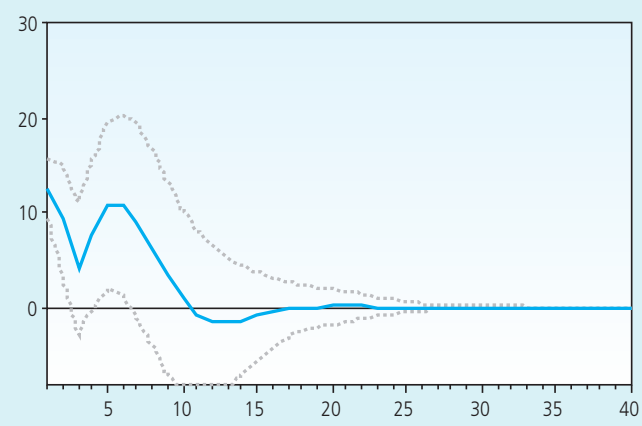

Response of SEKTOR_6 to SEKTOR_1

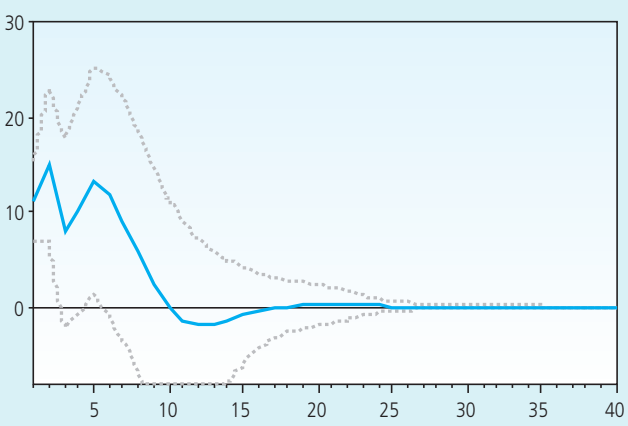

Response of SEKTOR_8 to SEKTOR_1

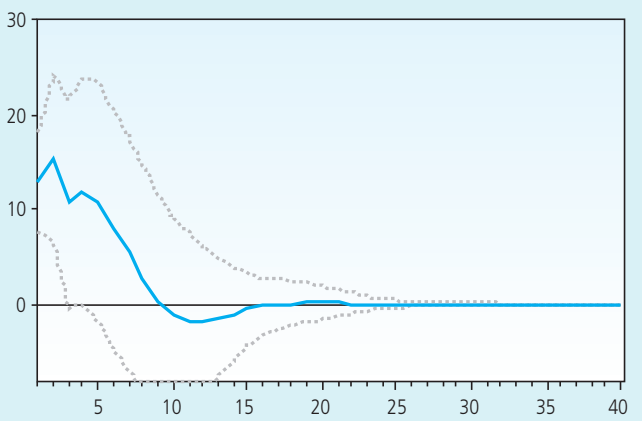

\section{Gambar II.4 Generalized Impulse Response Shock Risiko Sektor Pertanian (Sektor 1) (lanjutan)}

Terlihat bahwa shock berupa peningkatan risiko sektor pertanian sebesar 1 standar deviasinya menyebabkan naiknya risiko di sektor-sektor usaha lainnya. Hal ini menunjukkan adanya keterkaitan risiko sektor pertanian dengan risiko di sektor-sektor usaha lainnya, mengingat sektor pertanian merupakan sektor usaha yang menghasilkan bahan baku bagi beberapa sektor usaha lainnya. 
Sebagaimana risiko sektor pertanian, shock berupa peningkatan risiko sektor industri dasar dan kimia juga menyebabkan terjadinya peningkatan risiko di sektor-sektor usaha lainnya, sebagaimana grafik di bawah ini. Besar kecilnya response tiap sektor usaha mencerminkan pula keeratan hubungan antara sektor industri dasar dan kimia dengan sektor-sektor usaha lainnya tersebut.

Response of SEKTOR_1 to SEKTOR_3

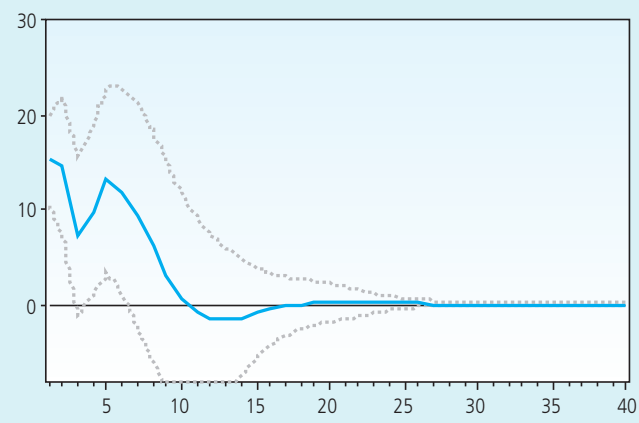

Response of SEKTOR_3 to SEKTOR_3

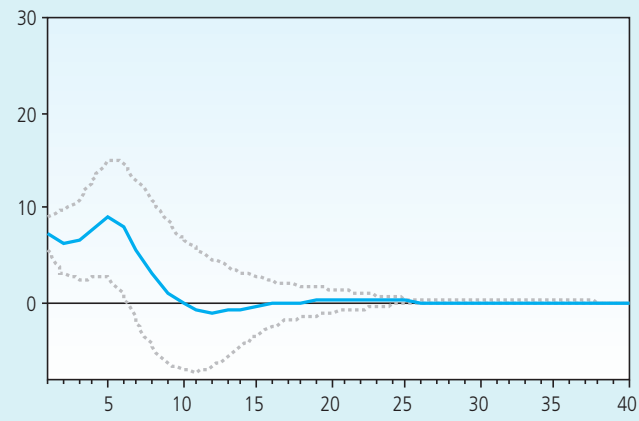

Response of SEKTOR_5 to SEKTOR_3

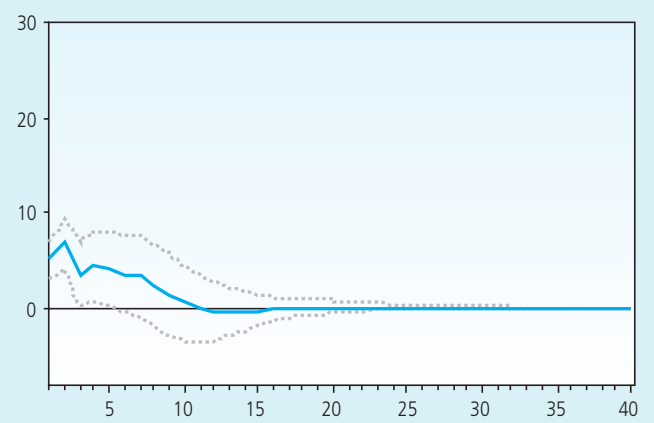

Response of SEKTOR_2 to SEKTOR_3

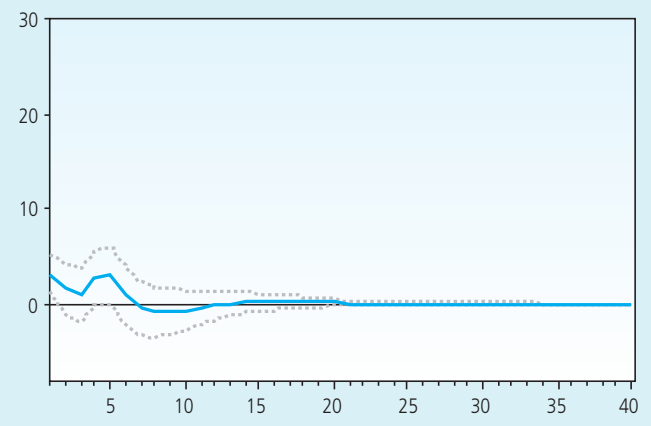

Response of SEKTOR_4 to SEKTOR_3

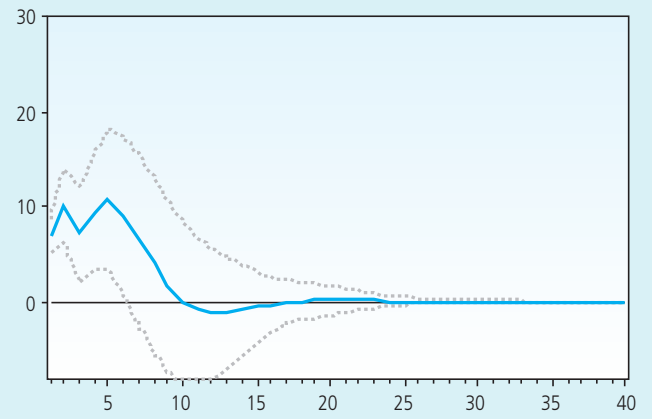

Response of SEKTOR_6 to SEKTOR_3

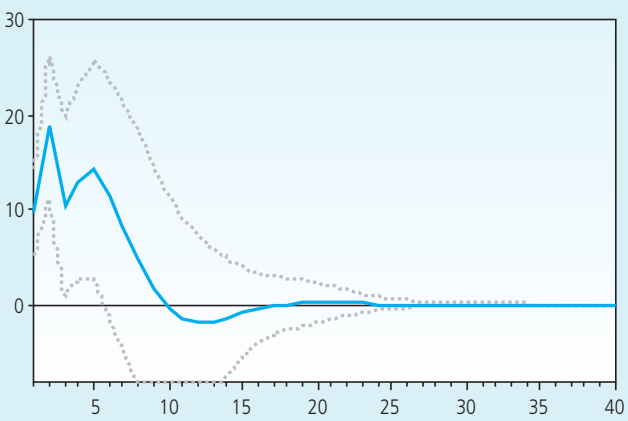

Gambar II.5 Generalized Impulse Response Shock Risiko Sektor Industri Dasar dan Kimia (Sektor 3) 
Response of SEKTOR_7 to SEKTOR_3

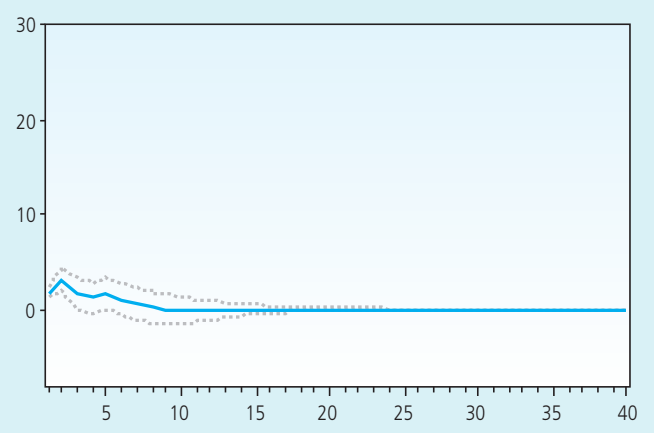

Response of SEKTOR_9 to SEKTOR_3

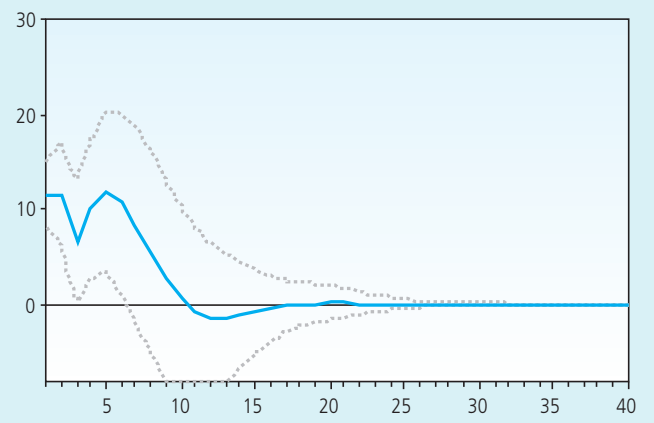

Response of SEKTOR_8 to SEKTOR_3

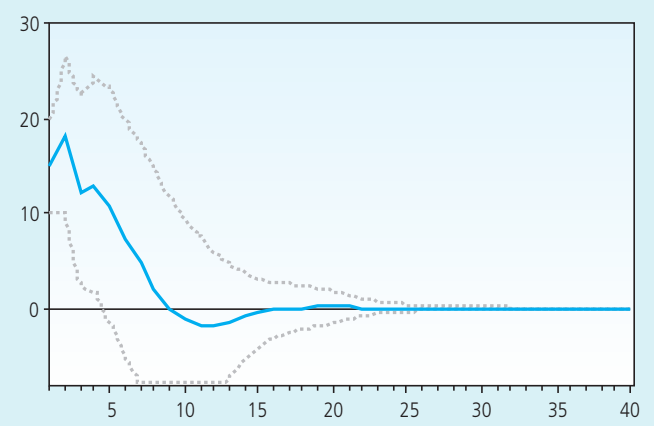

Gambar II.5 Generalized Impulse Response Shock Risiko Sektor Industri Dasar dan Kimia (Sektor 3) (lanjutan)

Keterkaitan risiko antar sektor usaha merupakan konsekuensi logis dari struktur inputoutput antar sektor usaha (hubungan backward dan forward-nya). Yang perlu dicermati dalam hal ini adalah seberapa besar dan seberapa cepat propagation effect dari peningkatan risiko di suatu sektor usaha terhadap risiko di sektor-sektor usaha lainnya.

Sementara itu pengaruh shock variabel-variabel ekonomi makro terhadap risiko pada masing-masing sektor usaha adalah sebagai berikut:

\section{IV.2.1. Pengaruh Tingkat Suku Bunga SBI}

Sebagaimana terlihat pada grafik di bawah ini, shock berupa peningkatan suku bunga SBI menyebabkan naiknya risiko di semua sektor usaha. Hal ini bisa dimengerti mengingat naiknya tingkat suku bunga SBI akan ditranslasikan dalam bentuk kenaikan tingkat suku bunga kredit dan dengan demikian cost of fund perusahaan menjadi lebih tinggi. 
Response of SEKTOR_1 to BIRATE

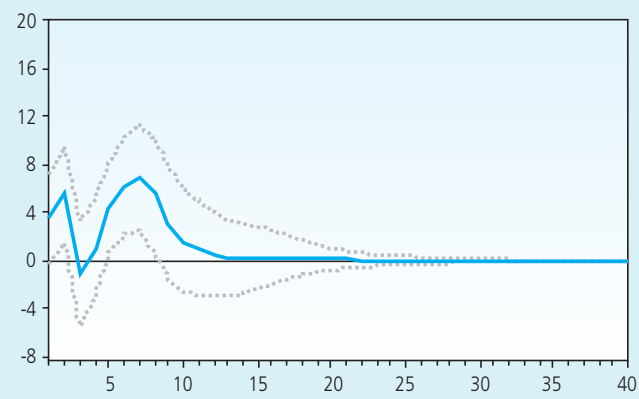

Response of SEKTOR_3 to BIRATE

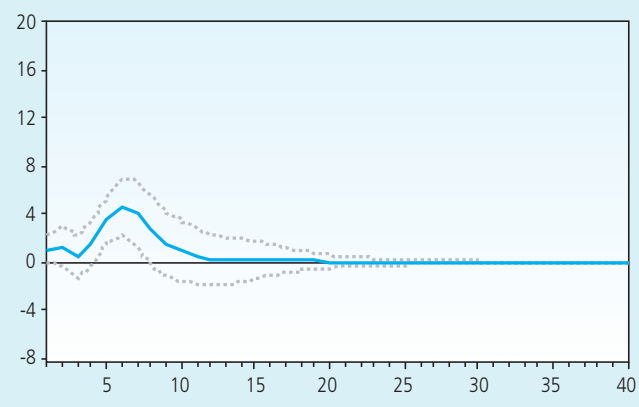

Response of SEKTOR_5 to BIRATE

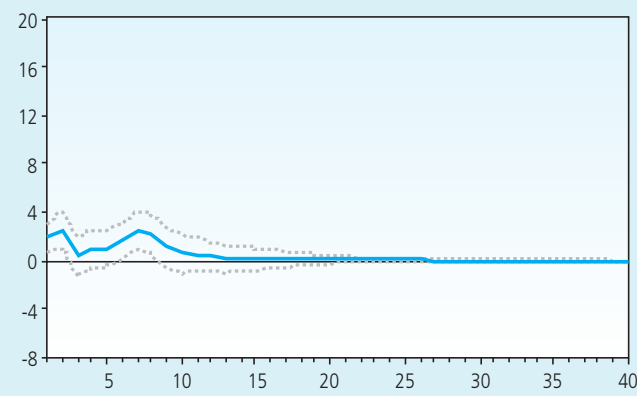

Response of SEKTOR_7 to BIRATE

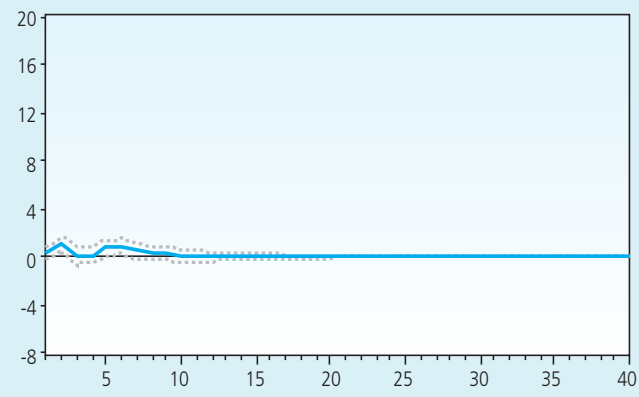

Response of SEKTOR_2 to BIRATE

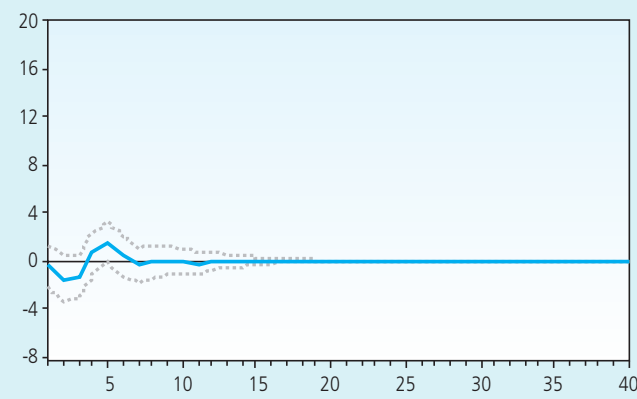

Response of SEKTOR_ 4 to BIRATE

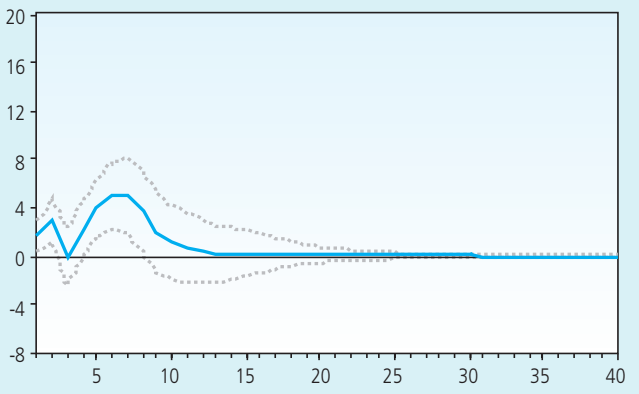

Response of SEKTOR_ 6 to BIRATE

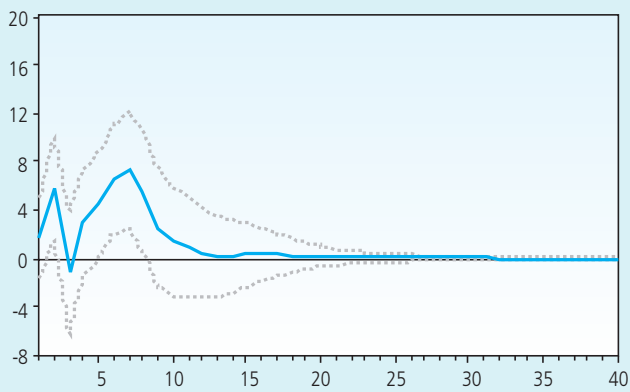

Response of SEKTOR_8 to BIRATE

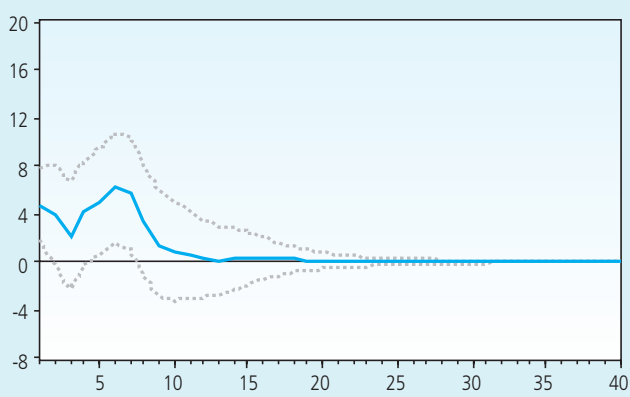

Gambar II.6 Generalized Impulse Response Shock Tingkat Suku Bunga SBI 
Response of SEKTOR_9 to BIRATE

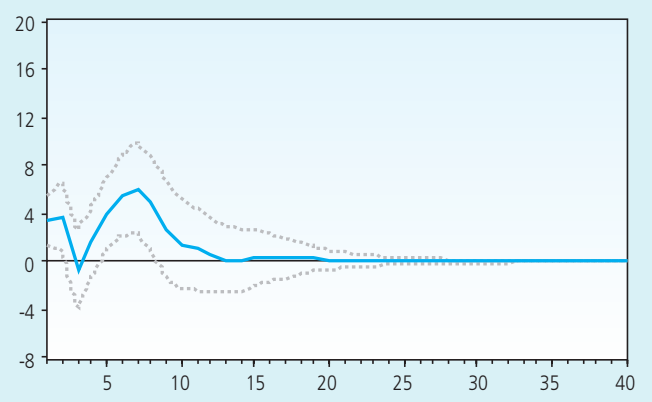

Gambar II.6 Generalized Impulse Response Shock Tingkat Suku Bunga SBI (lanjutan)

Semakin tinggi cost of fund perusahaan tentunya akan membuat perusahaan yang bersangkutan menghadapi penurunan profibtilitas dan dengan demikian kemampuan perusahaan dalam membayar hutang-hutangnya juga menurun. Kemungkinan terjadinya default tentunya akan meningkat. Perbedaan respon antar sektor usaha antara lain terkait dengan adanya perbedaan skala usaha, produk yang dihasilkan, capital intensity, struktur keuangan, dan akses perusahaan ke sumber-sumber pembiayaan alternatif.

\section{IV.2.2. Pengaruh Nilai Tukar}

Shock peningkatan nilai tukar nominal (USD/Rp) juga berdampak pada peningkatan risiko hampir di semua sektor usaha. Namun demikian terlihat dampaknya relatif lebih kecil dibandingkan dampak dari shock peningkatan suku bunga SBI. Nilai tukar tersebut terutama mempengaruhi perusahaan-perusahaan yang impor bahan bakunya relatif besar dan yang komposisi hutangnya dalam mata uang asing relatif besar.

Terdepresiasinya nilai Rupiah akan meningkatkan pendapatan perusahaan-perusahaan yang berorientasi ekspor. Namun di sisi lain biaya impor bahan baku juga meningkat. Bagi perusahaan-perusahaan yang transaksi penjualannya dalam mata uang Rupiah (ke pasar domestik), peningkatan biaya tersebut tentunya tidak disertai dengan peningkatan pendapatan. Hal tersebut tentunya akan meningkatkan risiko default perusahaan yang bersangkutan.

Di samping itu bagi perusahaan-perusahaan yang banyak berhutang dalam USD atau mata uang asing lainnya depresiasi nilai Rupiah tersebut tentunya akan menambah beban pembayaran hutang jika dinilai dalam mata uang Rupiah. Investor pun akan menilai harga pasar asset perusahaan tersebut lebih rendah. Kemungkinan default perusahaan yang bersangkutan menjadi semakin tinggi. 
Response of SEKTOR_1 to LEXRATE

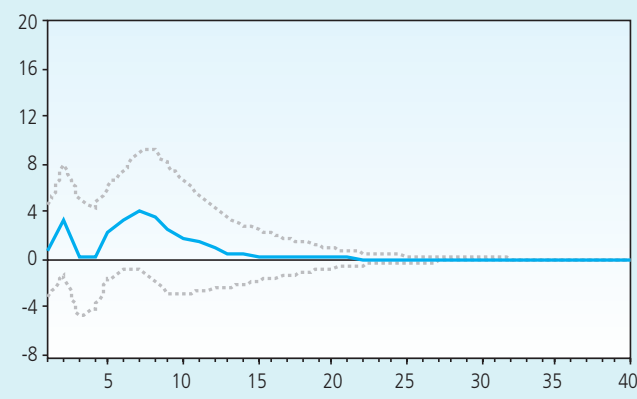

Response of SEKTOR_3 to LEXRATE

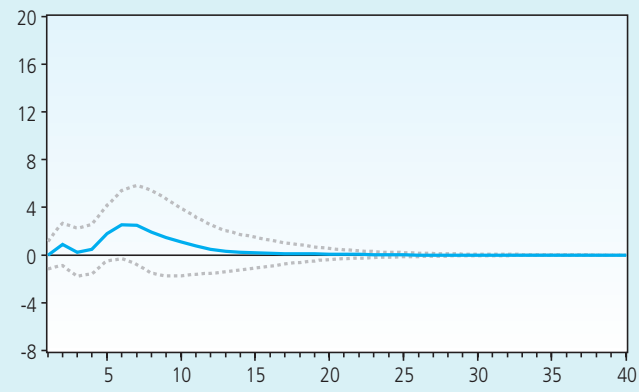

Response of SEKTOR_5 to LEXRATE

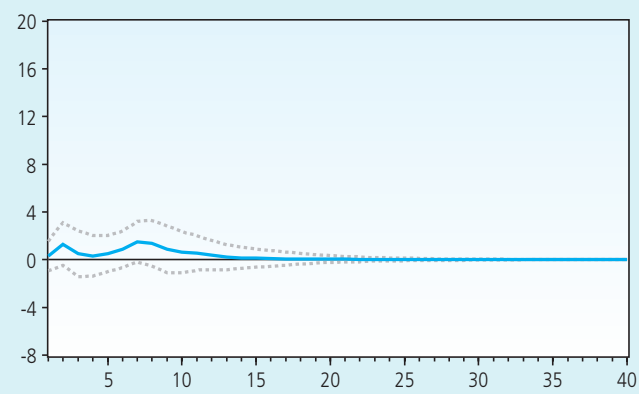

Response of SEKTOR_7 to LEXRATE

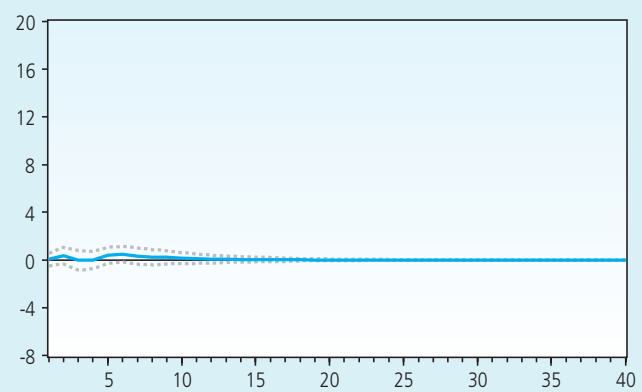

Response of SEKTOR_2 to LEXRATE

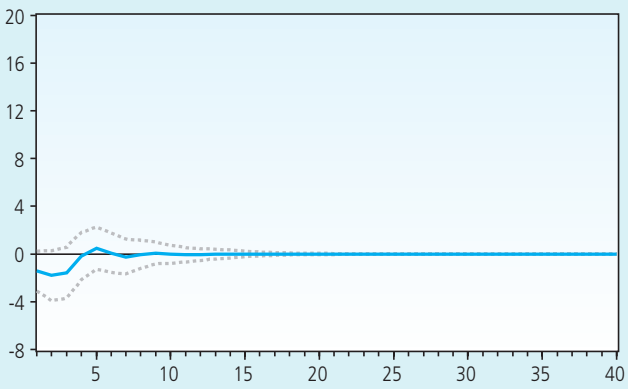

Response of SEKTOR_4 to LEXRATE

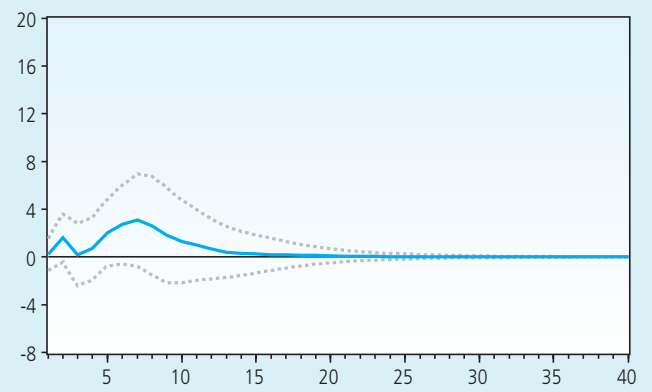

Response of SEKTOR_ 6 to LEXRATE

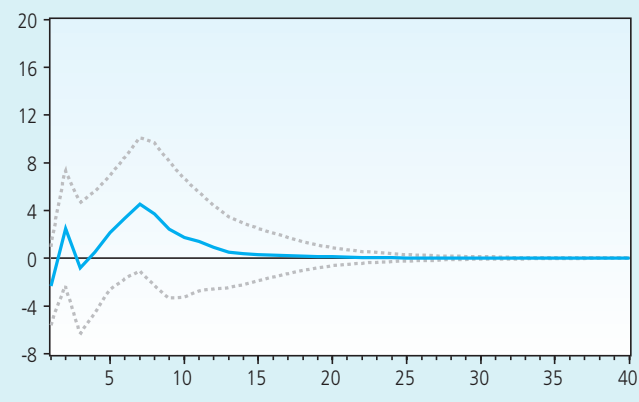

Response of SEKTOR_8 to LEXRATE

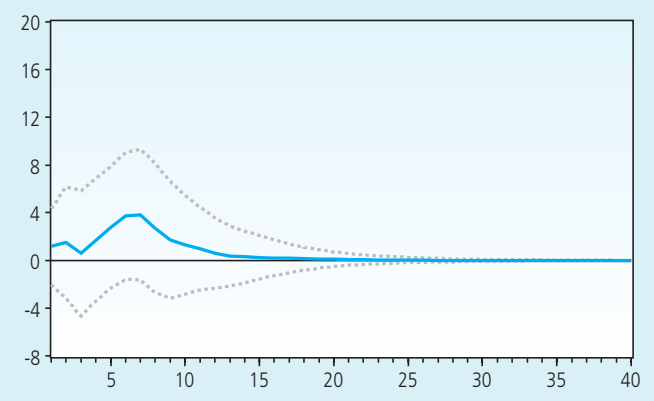

Gambar II.7 Generalized Impulse Response Shock Nilai Tukar 
Response of SEKTOR_9 to LEXRATE

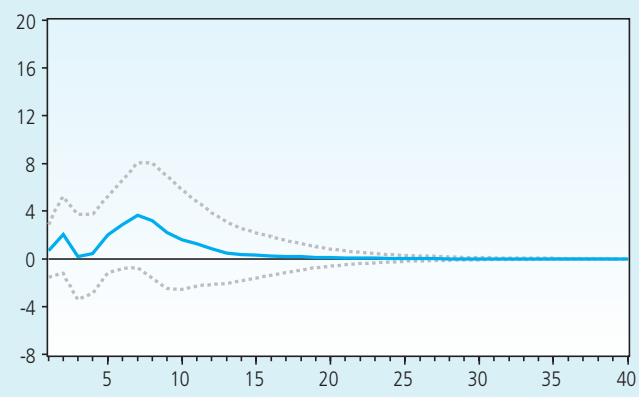

Gambar II.7 Generalized Impulse Response Shock Nilai Tukar (lanjutan)

\section{IV.2.3. Pengaruh Tingkat Inflasi}

Sementara itu shock berupa peningkatan inflasi juga menyebabkan naiknya risiko di semua sektor usaha, dengan besaran yang relatif tinggi. Peningkatan harga dapat menyebabkan turunnya volume penjualan dan profitabilitas perusahaan sehingga hal ini tentunya akan berdampak pada return on equity dan meningkatnya kemungkinan default perusahaan.

Response of SEKTOR 1 to INFLASI
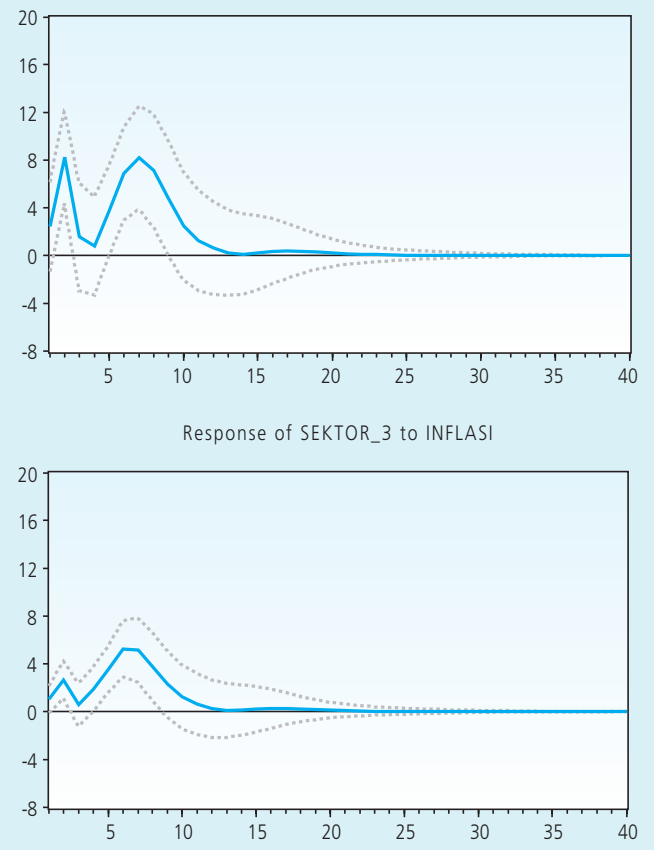

Response of SEKTOR 2 to INFLASI

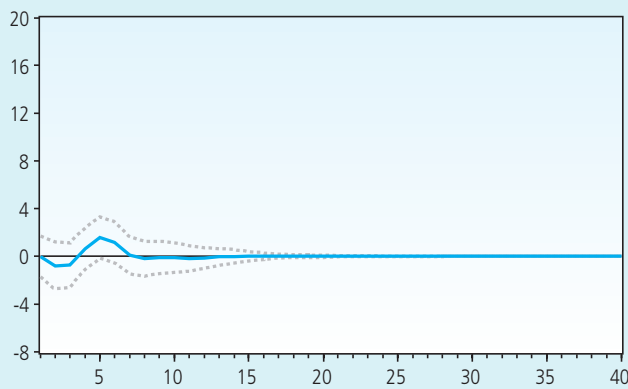

Response of SEKTOR_4 to INFLASI

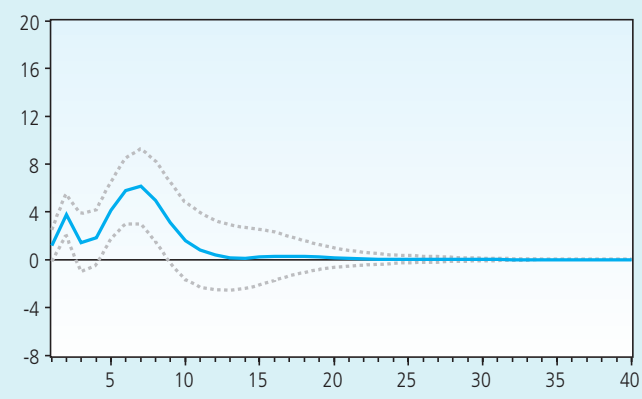

Gambar II.8 Generalized Impulse Response Shock Tingkat Inflasi 
Response of SEKTOR 5 to INFLASI

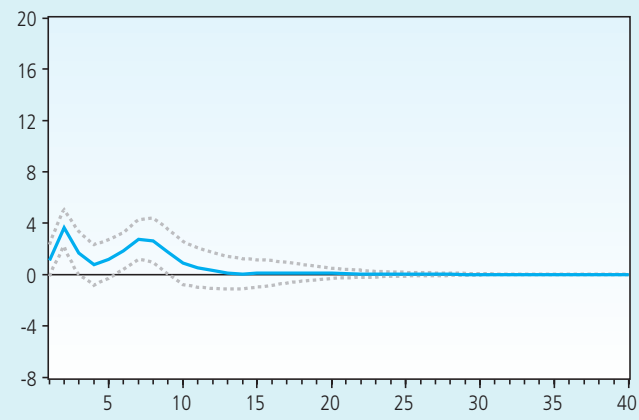

Response of SEKTOR_7 to INFLASI

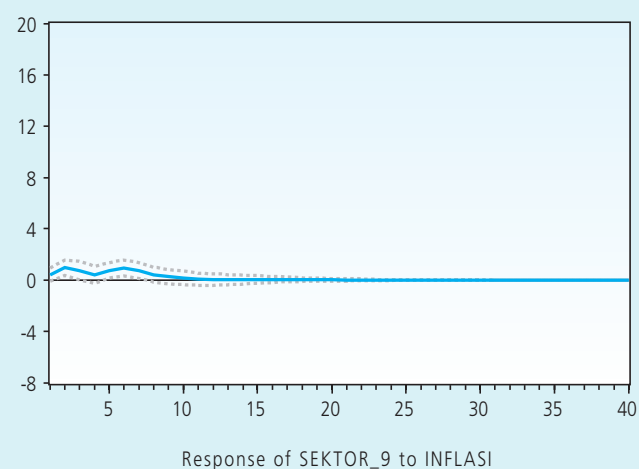

Response of SEKTOR_9 to INFLASI

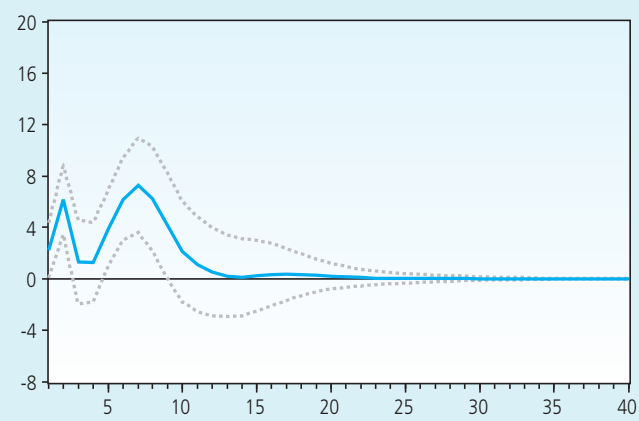

Response of SEKTOR 6 to INFLASI

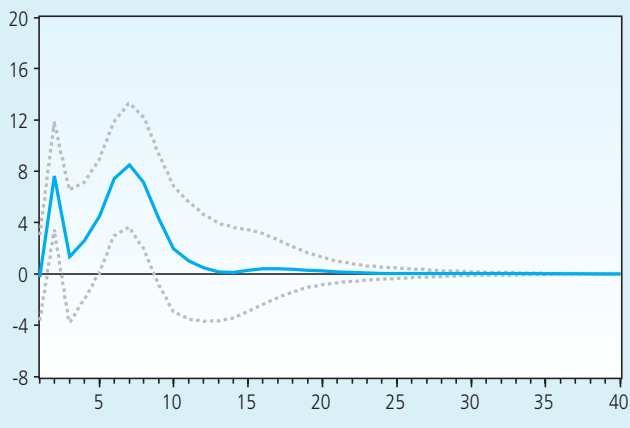

Response of SEKTOR_8 to INFLASI

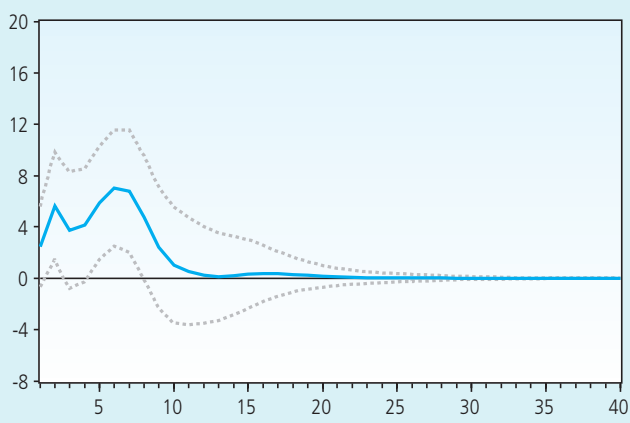

Gambar II.8 Generalized Impulse Response Shock Tingkat Inflasi (lanjutan)

Respon tiap perusahaan berbeda-beda, tergantung pada elastisitas permintaan produk yang dihasilkannya. Jika permintaannya elastis, maka total pendapatan perusahaan diperkirakan akan turun dan hal ini tentunya akan meningkatkan kemungkinan default perusahaan. Di samping itu perusahaan-perusahaan yang tidak dapat dengan mudah menyesuaikan harga produknya, misalnya karena adanya administered price atau posisinya pada suatu struktur pasar yang tidak memungkinkan untuk melakukan hal tersebut, akan menghadapi tekanan seiring dengan naiknya harga bahan baku. Dalam kondisi tersebut kemungkinan default perusahaan akan meningkat. 


\section{IV.2.4. Pengaruh Pertumbuhan Ekonomi}

Berbeda dengan ketiga variabel ekonomi makro di atas, shock peningkatan pertumbuhan ekonomi akan menyebabkan turunnya tingkat risiko di semua sektor usaha. Hal ini bisa dimengerti mengingat pertumbuhan ekonomi akan menyebabkan peningkatan penjualan dan profitabilitas perusahaan sehingga kemampuan perusahaan untuk melunasi hutang-hutangnya menjadi lebih baik.

Response of SEKTOR_1 to GDPGROWTH

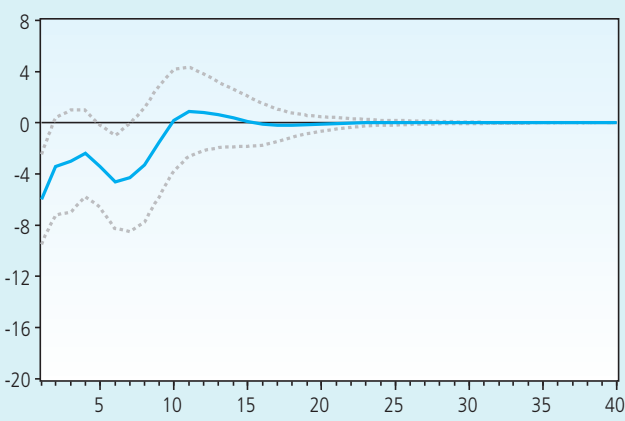

Response of SEKTOR_3 to GDPGROWTH

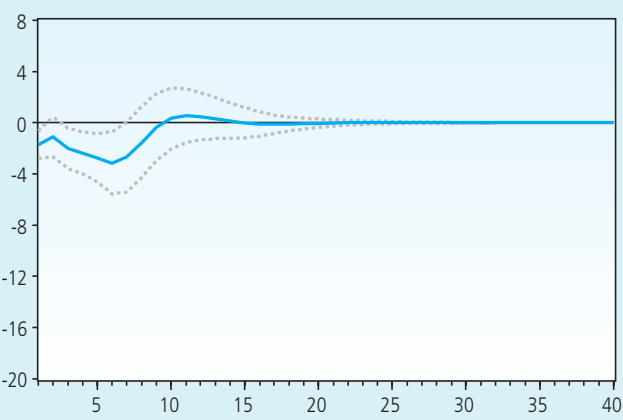

Response of SEKTOR_5 to GDPGROWTH

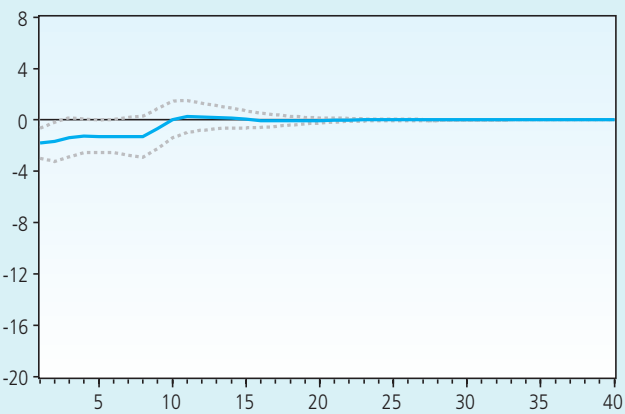

Response of SEKTOR_2 to GDPGROWTH

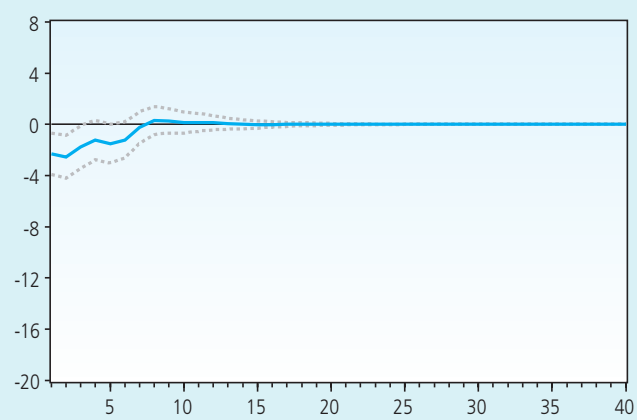

Response of SEKTOR_4 to GDPGROWTH

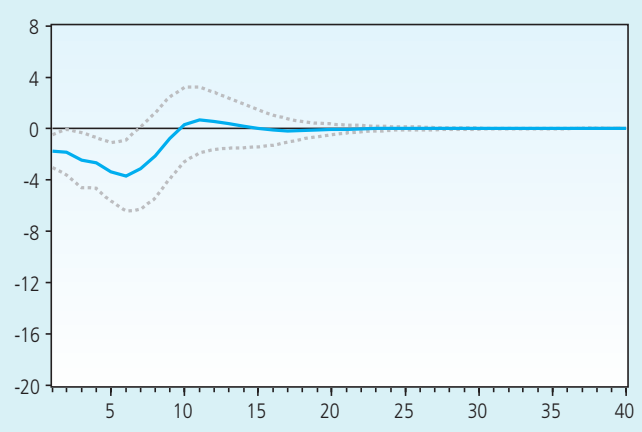

Response of SEKTOR_6 to GDPGROWTH

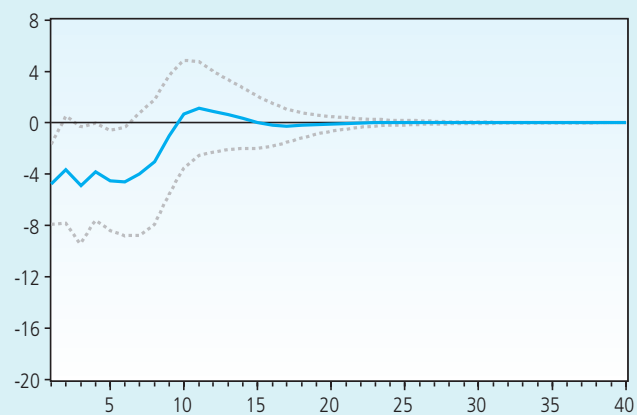

Gambar II.9 Generalized Impulse Response Shock Pertumbuhan Ekonomi 
Response of SEKTOR_7 to GDPGROWTH

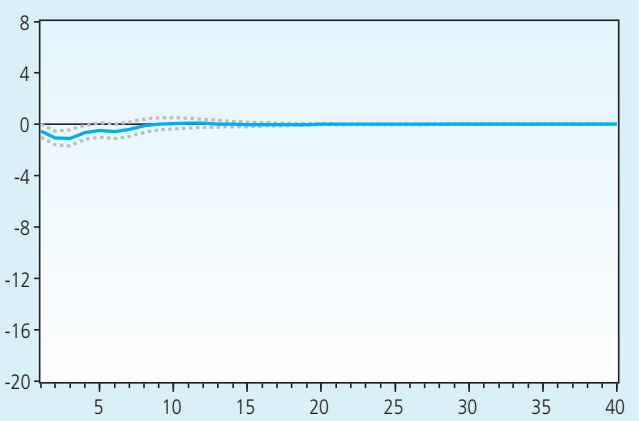

Response of SEKTOR_9 to GDPGROWTH

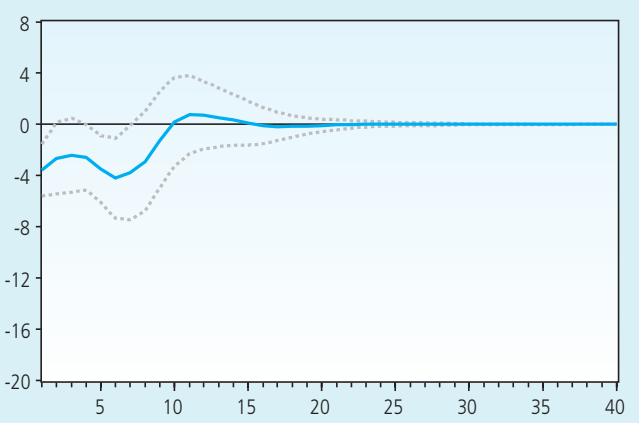

Response of SEKTOR_8 to GDPGROWTH

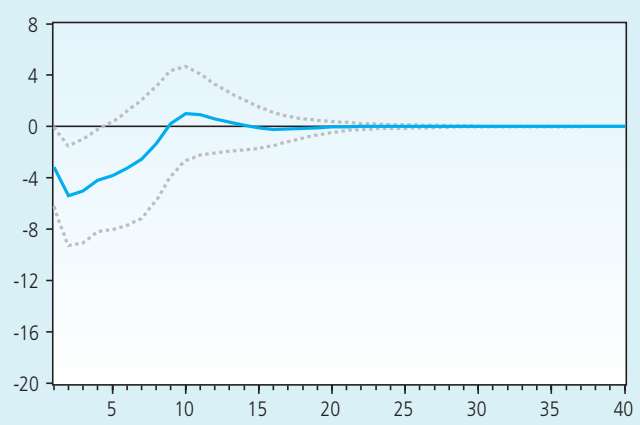

\section{Gambar II.9 Generalized Impulse Response Shock Pertumbuhan Ekonomi (lanjutan)}

Dari gambaran di atas terlihat adanya perbedaan respon risiko sektor usaha terhadap shock variabel-variabel ekonomi makro. Hal tersebut terkait dengan adanya perbedaan eksposure masing-masing sektor usaha terhadap variabel-variabel ekonomi makro tersebut. Untuk mengetahui dengan tepat hal tersebut tentunya perlu dilakukan penelitian lebih lanjut dengan menganalisis balance sheet effect dari shock variabel-variabel ekonomi makro tersebut.

Sementara itu melalui Variance Decomposition dapat dilihat peran tiap shock terhadap variasi pada suatu variabel endogen pada sistem VAR. Hasilnya menunjukkan bahwa variance pada variabel risiko sektoral banyak dipengaruhi oleh shock variabel tingkat suku bunga SBI, pertumbuhan ekonomi, dan inflasi. Sementara itu shock variabel nilai tukar relatif kecil pengaruhnya. Selain keempat variabel ekonomi makro tersebut, terlihat bahwa variance risiko suatu sektor usaha juga dipengaruhi oleh shock variabel risiko sektoral dari berbagai sektor usaha.

Sebagaimana diuraikan di muka, lambannya penyaluran kredit perbankan disinyalir disebabkan oleh tingginya risiko di sektor riil. Sebagaimana ditunjukkan pada Lampiran terlihat 
bahwa tidak ada hubungan yang sistematis antara besarnya kredit perbankan (dalam hal ini diukur dalam besaran riilnya) dan tingkat risiko di masing-masing sektor usaha. Namun demikian seiring dengan turunnya tingkat risiko pada sektor-sektor usaha tersebut sampai ke tingkat yang sangat rendah pada beberapa tahun terakhir, terlihat adanya pertumbuhan kredit perbankan.

\section{KESIMPULAN DAN REKOMENDASI}

\section{V.1. Kesimpulan}

Dari uraian di muka, dapat disimpulkan beberapa hal sebagai berikut:

1. Keterkaitan probability to default (EDF) antar sektor usaha sangat tinggi, yang terlihat dari besaran coefficient of correlation-nya. Hal ini tentunya semakin menguatkan hipotesis adanya keterkaitan risiko antar sektor usaha sehubungan dengan keterkaitan backward dan forward dari sektor-sektor usaha tersebut.

2. Keterkaitan risiko antar sektor usaha tersebut ditunjukkan oleh peningkatan risiko suatu sektor usaha yang diikuti dengan peningkatan risiko di sektor-sektor usaha lainnya. Keterkaitan risiko antar sektor usaha merupakan konsekuensi logis dari struktur input-output antar sektor usaha (hubungan backward dan forward-nya). Yang perlu dicermati dalam hal ini adalah seberapa besar dan seberapa cepat propagation effect dari peningkatan risiko di suatu sektor usaha terhadap risiko di sektor-sektor usaha lainnya.

3. Pengaruh variabel-variabel ekonomi makro terhadap risiko sektoral dapat diikhtisarkan sebagai berikut:

a. Peningkatan suku bunga SBI, nilai tukar nominal (USD/Rp), dan inflasi akan menyebabkan naiknya risiko hampir di semua sektor usaha. Hal ini terkait dengan pengaruh variabelvariabel tersebut terhadap balance sheet dan kinerja (penjualan dan biaya) perusahaan.

b. Peningkatan pertumbuhan ekonomi akan menyebabkan turunnya tingkat risiko di semua sektor usaha. Hal ini bisa dimengerti mengingat pertumbuhan ekonomi akan menyebabkan peningkatan penjualan dan profitabilitas perusahaan sehingga kemampuan perusahaan untuk melunasi hutang-hutangnya menjadi lebih baik.

\section{V.2. Rekomendasi}

Beberapa hal yang bisa direkomendasikan dari penelitian antara lain sebagai berikut:

1. Mengingat dampaknya terhadap risiko sektoral, Bank Indonesia harus berupaya untuk menekan tingkat suku bunga SBI dan inflasi serta menjaga nilai tukar Rupiah. Dengan 
demikian diharapkan tingkat risiko sektoral di Indonesia dapat dijaga serendah mungkin. Di sisi lain pertumbuhan ekonomi mesti diupayakan lebih tinggi guna menurunkan tingkat risiko sektoral.

2. Perlu dilakukan penelitian lebih lanjut untuk menganalisis balance sheet effect dari shock variabel-variabel ekonomi makro tersebut guna mengetahui penyebab perbedaan pengaruh shock variabel-variabel ekonomi makro terhadap risiko sektoral.

3. Penelitian ini diharapkan bisa dijadikan referensi bagi penelitian-penelitian lain. Sementara itu pemodelan pada penelitian ini dapat dikembangkan lebih lanjut dengan memodelkan hubungan fungsional antar variabel risiko sektoral. 


\section{DAFTAR PUSTAKA}

Ali, Masyhud. Asset Liability Management: Menyiasati Risiko Pasar dan Risiko Operasional dalam Perbankan. Jakarta: Gramedia, 2004.

Alves, Ivan. "Sectoral Fragility: Factors and Dynamics." BIS Papers, No. 22, 2005.

Cipollini, Andrea dan Missaglia, Giuseppe. Dynamic Factor Analysis of Industry Sector Default Rates and Implication for Portfolio Credit Risk Modelling. November 2006.

Crosbie, Peter dan Bohn, Jeff. Modeling Default Risk: Modeling Methodology. Moody's KMV, 2003.

Harris, Richard. Using Cointegration Analysis in Econometric Modelling. London: Prentice HallHarvester Wheatsheaf, 1995.

Kurbat, Matthew dan Korablev, Irina. Methodology for Testing the Level of the EDF Credit Measure. Moody's KMV, Agustus 2002.

Pesaran, M. Hashem; Schuermann, Til; Treutler, Björn-Jakob; dan Weiner, Scott M. Macroeconomic Dynamics and Credit Risk: A Global Perspective. Federal Reserve Bank of New York, April 2005.

Sorge, Marco dan Virolainen, Kimmo. "A Comparative Analysis of Macro Stress-Testing Methodologies with Application to Finland." Journal of Financial Stability, 2006, 2(2006), 113-151. 


\section{LAMPIRAN}

\section{Kredit Perbankan dan Risiko Sektoral}
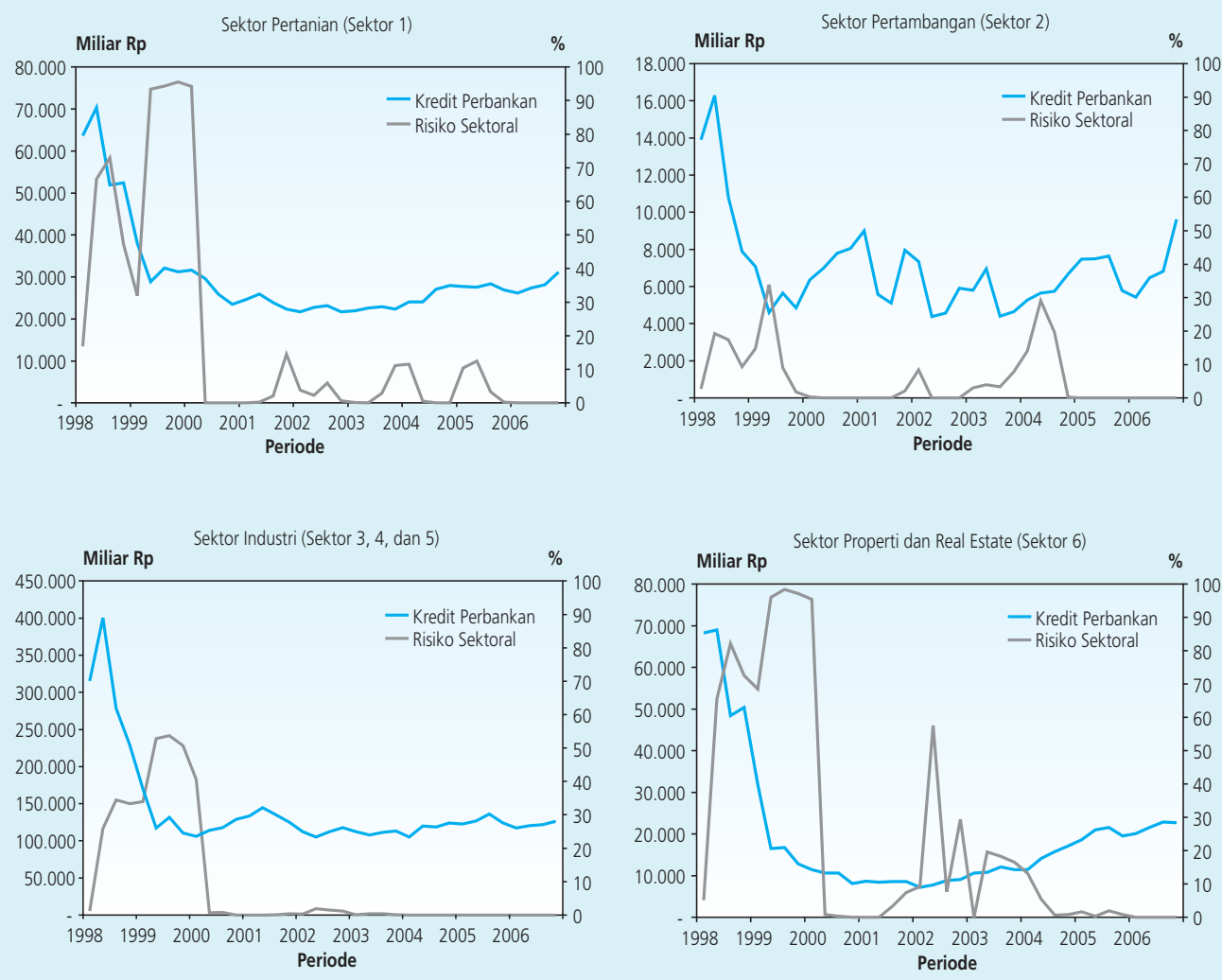

Sektor Infrastruktur, Utilitas, dan Transportasi (Sektor 7)

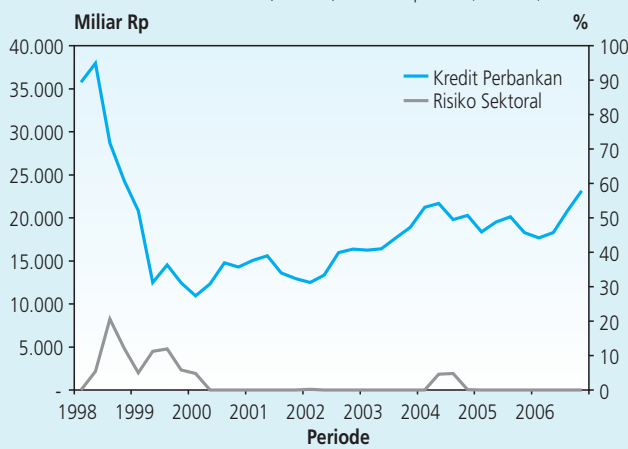

Sektor Perdagangan, Jasa, dan Investasi (Sektor 9)

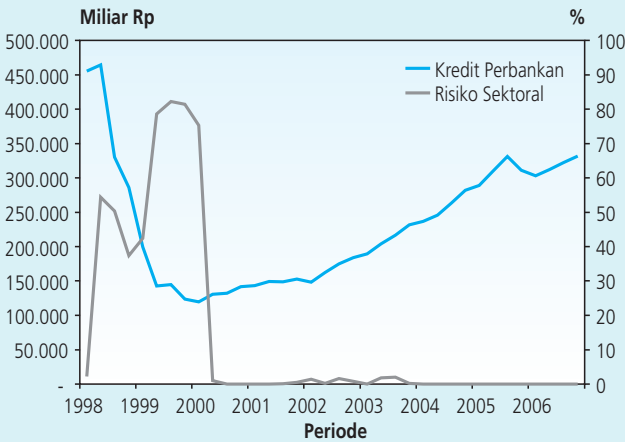

